\title{
Korean Firms' Share Repurchase Activities: Firm Characteristics, Financing and Investment ${ }^{*}$
}

\author{
Jin Park, Research Professor, Korea University of Technology \& Education
}

Hyunseok Kim, Visiting Professor, Sungkyunkwan University

Jungwon Suh ${ }^{* *}$, Professor, Sungkyunkwan University

\begin{abstract}
$\langle$ Abstract $\rangle$
This study examines Korean listed firms' share repurchasing activities over the period 2006 2016 using the amount of net share repurchases from annual statements of cash flow. Korean firms use dividends rather than share repurchases as their primary payout method. Each year, the proportion of share repurchasing firms is lower than $20 \%$, whereas the proportion of dividend-paying firms is around $70 \%$ or higher. Univariate analysis and Tobit regressions reveal that the incidence and amount of share repurchases increase with firm value, size, and cash flow. Our findings do not suggest that low valuations (or poor stock performance) or low debt ratios motivate share repurchases. Korean firms use primarily internal funds to finance share repurchases, as share repurchasing firms experience substantial increases in retained earnings. Share repurchasing firms do not invest less than other firms do, suggesting that share repurchases do not result in underinvestment. Compared to dividends, share repurchases are more positively associated with firm value. Compared to share repurchase, dividends are more positively associated with cash flow and financial maturity, but more negatively associated with stock return volatility. Finally, firms with high controllingshareholders' ownership tend to choose dividends over share repurchases in their payout policy.
\end{abstract}

Keywords: Share Repurchases; Firm Value; Dividends; Cash Flow; Corporate Investment JEL Classification: G31, G32, G35

* This work was supported by the Ministry of Education of the Republic of Korea and the National Research Foundation of Korea (NRF-2018S1A5A2A01028591).

** Corresponding Author. Address: Business School, Sungkyunkwan University, 25-2 Sungkyunkwan-ro, Jongno-gu, Seoul, Korea 03063; E-mail: jungwonsuh@skku.edu; Tel: +82-2-760-0482; Fax: +82-2-760-0440.

Received: April 24, 2020; Revised: September 07, 2020; Accepted: October 06, 2020 


\title{
한국 상장기업 자사주매입 활동의 특질
}

\author{
박 진 (한국기술교육대학교 연구교수) \\ 김 현 석 (성균관대학교 초빙교수) \\ 서 정 원 (성균관대학교 교수)**
}

\begin{abstract}
본 연구는 2006 2016년 기간 유가증권시장 소속기업의 자사주매입과 관련을 가지는 기업특성과 그 재원을 분석하고 기존 가설을 검증하였다. 국내 기업은 자사주매입보다는 배당을 주된 지급수단으로 사용하고 있으며 연도별 자사주매입(배당지급) 기업의 비율은 대체로 $20 \%$ 이하(70\% 이상)였다. 자사주 매입의 규모는 기업가치가 높을수록, 기업규모가 클수록, 현금흐름이 우수할수록 높게 나타났다. 저평가된 기업이 자사주매입을 실시한다는 주가저평가가설과 부채비율을 높이기 위한 수단으로 실시한다는 레버리지가설은 지지되지 않았다. 자사주매입 실시기업의 주 재원은 현금흐름(즉 내부창출자금)으로 보이며 부채조달과 기존 보유현금의 역할은 낮아 보였다. 자사주매입 실시기업은 미실시기업에 비해 적극투자 빈도가 높은 것으로 나타나 과소투자가설은 지지되지 않았다. 자사주매입은 (배당과 비교해) 기업가치가 높을수록 그 규모가 커지며, 배당지급은 (자사주매입과 비교해) 현금흐름이 좋거나 재무적 성숙도가 높을수록 그 규모가 커지며 주가변동성이 높을수록 그 규모가 작아지는 경향이 나타났다. 또한 대주주지분율이 낮을수록 자사주매입을 실시하는 경향이 높으며 대주주지분율이 높을수록 배당지급 규모가 커지는 경향이 나타났다.
\end{abstract}

핵심 단어 : 자사주매입, 기업가치, 배당, 현금흐름, 기업투자

JEL 분류기호: G31, G32, G35

* 이 논문은 2018년 대한민국 교육부와 한국연구재단의 지원을 받아 수행된 연구임 (NRF-2018S1A5A2A01028591).

** 연락담당 저자. 주소: 서울특별시 종로구 성균관로 25-2 성균관대학교 경영대학, 03063; E-mail: jungwonsuh@skku.edu; Tel: 02-760-0482; Fax: 02-760-0440. 


\section{1. 서론}

본 연구의 목적은 한국기업의 자사주매입 활동의 규모, 실시기업의 특질, 재원 등을 분석하고 기존 자사주매입 관련 가설을 평가하는 데 있다. 국내 선행연구들은 주로 2000년대 초까지의 자사주매입 기업의 특성을 분석하였기 때문에 최근 한국기업의 자사주매입 행태의 특질과 성격에 대해서는 연구성과가 부재한 실정이다. 미국기업의 자사주매입을 분석한 선행연구들은 주로 현금흐름표 상 자사주매입 지출액(Compustat 데이터코드 PRSTKC)을 이용해 개별기업의 연도별 자사주매입 실적을 측정하여 그 결정요인을 분석하였다(Dittmar, 2000 등). 하지만 최근까지 FnGuide 등의 국내 주요 데이터베이스에는 현금흐름표의 자사주매입 지출액이 누락되어 있었기 때문에 미국의 선행연구와 비교가능한 연구가 사실상 불가능하였다. 따라서 국내 선행연구들은 자사주매입 건별 공시자료를 이용해 국내 기업의 자사주매입 활동을 분석해 왔는데 Byun(2004) 등이 지적하였듯이 자사주매입 공시규모는 허위공시의 문제로 실제 실적규모 와는 큰 괴리가 있는 등의 문제가 있다.

본 연구는 현재 FnGuide 데이터베이스로부터 연도별 자사주매입 금액이 추출 가능한 2006년을 연구표본 시작년도로 설정하여 2016년까지의 기간을 대상으로 유가증권시장 소속기업의 자사주 매입 활동을 분석하였다. 자사주매입 규모는 순매입금액(=자사주매입금액-자사주처분금액) 으로 측정하였으며 순매입금액이 양(+)인 기업연도를 자사주매입 실시기업으로 정의하였다. 본격적인 분석에 앞서 <그림 1>은 2006 2016년 기간 유가증권시장 기업의 자사주매입과 배당의 규모를 그래프로 보고하는데, 유가증권시장 기업은 자사주매입보다는 배당을 주된 현금지급수단으로 사용하고 있음을 알 수 있다. 패널 $\mathrm{A}$ 가 보고하듯이 모든 연도에서 총 배당 지급액이 총 자사주매입 액을 크게 상회하였으며, 패널 $\mathrm{B}$ 가 보고하듯이 유가증권시장 전체기업 중 배당지급 기업(즉, 배당지급액이 양(+)인 기업)의 비율은 모든 연도에서 자사주매입 실시기업 (즉, 자사주 순매입금액이 양(+)인 기업)의 비율보다 압도적으로 높았다.

위에 서술된 정의에 따라 자사주매입 실시기업으로 분류되어 자사주매입 실시표본에 포함된 기업연도는 모두 1,071 건(고유기업 수 396 개)인데, 이중 2 년 연속 실시기업 비율(즉, $\mathrm{t}=0$ 과 $\mathrm{t}=1$ 모두 실시하는 기업의 비중)은 $52.5 \%, 3$ 년 연속 실시기업 비율(즉, $\mathrm{t}=0, \mathrm{t}=1, \mathrm{t}=2$ 모두 실시하는 기업의 비중)은 $31.0 \%$ 로 나타나 자사주매입이 상당한 연속성을 나타냈다. 자사주매입 실시표본에 포함된 자사주매입 실시기업과 포함되지 않은 미실시기업 간의 재무적 특성 차이를 단변량 분석을 통해 실시한 결과, 자사주매입 실시기업은 미실시기업보다 기업규모가 크고 기업가치 $(\mathrm{M} / \mathrm{B}$ 비율)가 높으며 현금흐름이 우수한 것으로 나타났다. 또한 자사주매입 실시기업은 이익잉여금비율, 총자산 증가율, 현금비율, 배당 규모가 모두 높은 반면 부채비율은 낮고 주가 변동성은 작은 것으로 나타났다. 직전년도 주가수익률은 자사주매입 실시기업과 미실시기업 간에 유의한 차이가 나타나지 않았다.

자사주매입 실시기업과 미실시기업을 모두 포함한 표본에 대해 Tobit 회귀분석을 실시하여 자사주매입에 영향을 미치는 기업특성을 식별하고자 하였다. 회귀식의 종속변수로는 당해연도 자사주매입 규모(자사주매입 $\mathrm{t}$ 총자산 $\mathrm{t}_{-1}$ )와 3년치 누적자사주 매입규모( $\sum$ 자사주매입 $(\mathrm{t}, \mathrm{t}+2) /$ 
총자산 $\mathrm{t}_{-1}$ )를 사용하였다. 분석 결과 $\mathrm{M} / \mathrm{B}$ 비율은 자사주매입 규모에 유의한 양 $(+)$ 의 영향을 미치며 직전년도 주가수익률은 유의한 영향을 미치지 않았다. 이는 기업가치가 낮거나 주가실적이 저조한 기업이 자사주매입을 실시한다는 주가저평가가설을 지지하지 않는다. 부채비율은 자사주매입 규모에 유의한 영향을 미치지 않는 것으로 나타나 부채비율을 증가시킬 목적으로 자사주매입을 실시한다는 레버리지가설 또한 지지되지 않았다. 기업규모와 현금흐름은 자사주 매입 규모에 일관되게 유의한 양(+)의 영향을 미치는 것으로 나타났다. 따라서 기업가치가 높은 기업일수록, 대기업일수록, 현금흐름이 좋은 기업일수록 자사주매입을 실시하거나 자사주 매입 규모가 큰 것으로 나타났다.

〈그림 1〉유가증권시장 전체기업의 자사주매입 vs. 배당 실적 비교 2006 2016년 기간에 대해 유가증권시장 전체기업을 대상으로 계산된 총 자사주매입과 총 배당의 연도별 실적을 그래프로 보고한다. 패널 $\mathrm{A}$ 는 자사주 순매입금액(자기주식의 취득-자기주식의 처분)과 배당지급액 각각의 전체기업 총합을 연도별로 계산하여 비교하였다. 전체기업 총합은 FnGuide 데이터베이스로부터 개별기업 실적치를 구한 후 전체기업에 대해 합한 값이다. 패널 $\mathrm{B}$ 는 전체기업 중 자사주매입 기업(i.e., 자사주 순매입금액이 양 $(+)$ 인 기업)의 비율과 배당지급 기업(i.e., 배당지급액이 양( $(+)$ 인 기업)의 비율을 비교한다. 금융회사, 매출액 누락, 자본총계가 음(-)인 기업은 분석에서 제외하였다.

패널 $\mathrm{A}$ : 총 자사주 순매입금액 vs. 총 배당지급액(단위: 억 원)

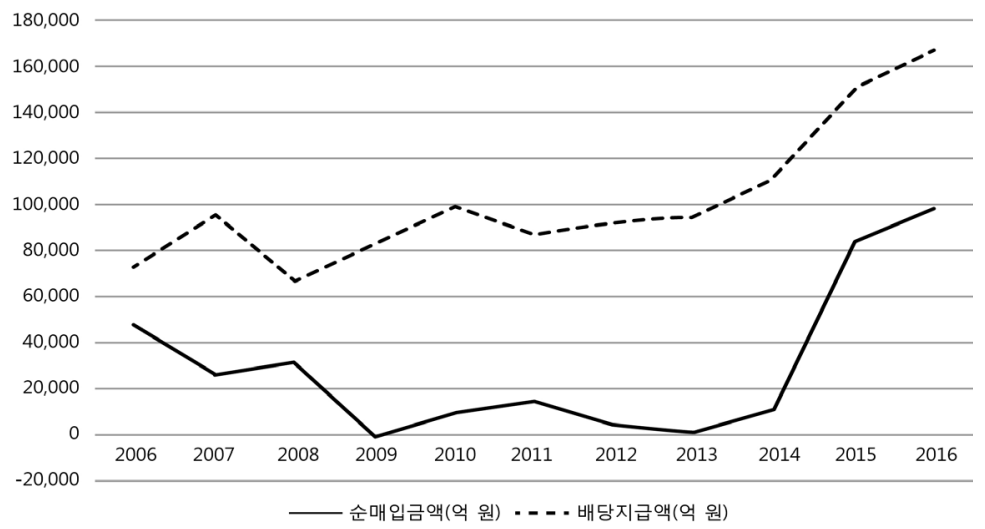

패널 B: 자사주매입 실시기업 비율 vs. 배당지급 기업 비율

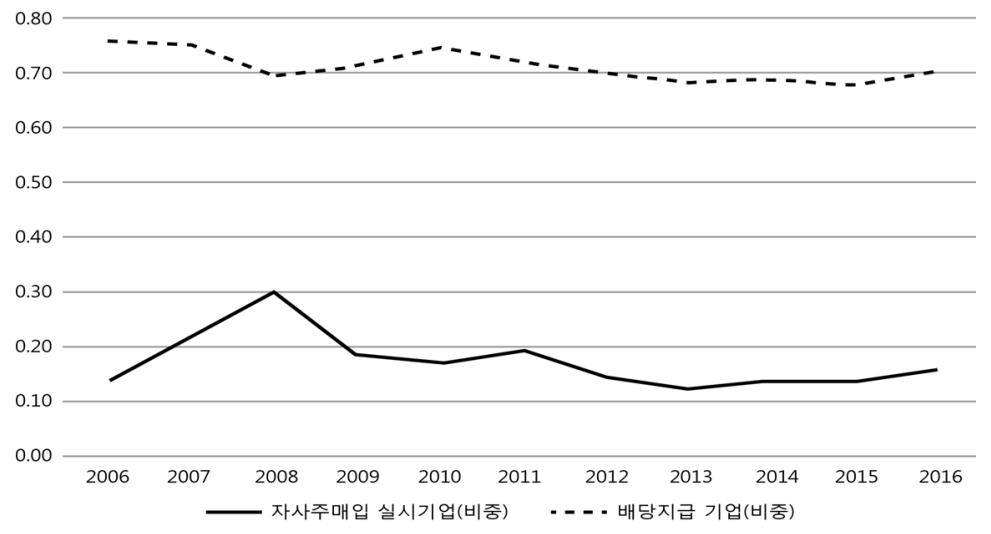


한국증권학회지 제49권 5호 (2020)

또한 자사주매입 실시기업의 주요 성장률과 자본구조 변화를 관찰함으로써 자사주매입의 주된 재원을 가늠하고자 하였다. 자사주매입기업은 높은 수준의 현금흐름 창출력을 나타내는데 이는 자사주매입의 주 재원이 현금흐름(즉 내부창출자금)일 가능성을 시사한다. 이 관측과 일관되게 자사주매입 실시기업(특히 실시규모 상위기업)의 이익잉여금의 증가가 부채 등 다른 구성요소의 변화보다 매우 크게 나타났다. 또한 자사주매입 기업은 평균과 중간값 기준으로 보유현금 감소가 발생하지 않는 것으로 보아 자사주매입 실시의 주된 재원은 부채조달이나 보유현금보다는 현금흐름으로 추정된다.

그런데 자사주매입 실시기업은 현금흐름을 사업에 재투자할 수 있음에도 불구하고 자사주 매입을 실시함으로써 성장기회를 살리지 못한다는 우려가 있을 수 있다. 이를 분석하기 위해 Biddle et al.(2009)의 방법론을 이용해 자사주매입 기업이 소극 또는 적극 투자를 하는 비율을 추정하였다. 전체 유가증권시장 기업에 대해서는 소극투자 비율이 $25 \%$, 중립투자 비율이 $50 \%$, 적극투자 비율이 25\%로 나타나도록 연구 설계하였는데, 추정 결과 자사주매입 기업은 소극투자 비율이 $18.84 \%$, 중립투자 비율이 50.98\%, 적극투자 비율이 $30.18 \%$ 로 나타나, 자사주매입 기업은 다른 기업에 비해 소극투자보다는 적극투자의 성향이 높았다. 또한 자사주매입 기업은 산업과 기업규모를 기준으로 선정한 자사주매입 미실시 매칭기업에 비해서도 소극투자의 비율은 낮고 적극투자의 비율은 높게 나타났다. 따라서 분석 결과는 자사주매입 기업이 투자에 소극적이라는 우려를 지지하지 않는다.

마지막으로 지급수단으로써 자사주매입의 성격을 배당과 비교하기 위해 주요 기업특질이 자사주매입에 미치는 효과를 배당에 미치는 효과와 비교하여 분석하였다. 분석 결과 자사주매입 규모는 배당지급 규모와는 달리 $\mathrm{M} / \mathrm{B}$ 비율과 유의한 양(+)의 관계를 나타내어 자사주매입은 (배당과는 달리) 기업가치가 높을수록 그 규모가 더 커지는 경향이 있다. 한편 배당지급 규모는 자사주매입 규모와 비교해 현금흐름 및 이익잉여금비율과의 양(+)의 관계가 더 강하였고 주가변동성과의 음(-)의 관계가 더 강하게 나타났다. 또한 대주주지분율이 낮은 기업은 높은 기업에 비해 자사주매입을 실시하는 경향이 강하게 나타났으며, 대주주지분율이 높은 기업은 낮은 기업에 비해 배당지급 규모가 큰 경향이 강하게 나타났다.

본 연구는 국내 선행연구와는 달리 기업의 현금흐름표 상 연간 자사주매입 규모를 이용하여 한국기업의 자사주매입 의사결정에 미치는 기업특성을 분석하였다. 또한 선행연구는 주로 1990년대 또는 2000년대 초까지의 자사주매입의 특질을 분석하였는데 반해 본 연구는 최근 기간(2006 2016년)의 자사주매입을 분석하였으며 선행연구가 분석하지 않은 자사주매입의 재원, 자본구조와의 관련성, 배당지급과의 특성 차이 등을 분석하였다.

본 연구의 주요 분석 결과와 시사점을 정리하면 다음과 같다.

(1) 국내 상장기업은 자사주매입보다는 배당지급을 주된 지급수단으로 사용하고 있다. 예를 들어 분석기간 동안 연도별 배당지급 기업의 비율은 $70 \%$ 수준 또는 그 이상인데 반해 자사주매입 실시기업의 비율은 대체로 $20 \%$ 이하의 비율을 나타내었다.

(2) 기업가치가 높을수록, 기업규모가 클수록, 현금흐름이 우수할수록 자사주매입을 실시 하거나 그 규모가 커지는 경향이 있다. 자사주매입 실시는 높은 수준의 총자산 성장률과 
현금흐름 창출을 동반하는데 이는 기업가치가 높은 기업이 자사주매입을 실시한다는 관측과 일관된 것이다.

(3) 자사주매입 실시의 주 재원은 부채조달 또는 기존 보유현금보다는 현금흐름(즉 내부창출 자금)으로 보인다. 구체적으로 자사주매입 기업은 현금흐름을 내부유보하면서 자사주 매입을 실시하는 것으로 보이며 이 관측과 일관되게 자사주매입 실시기업의 자본구조 구성요소 중 이익잉여금의 증가가 높게 나타났다.

(4) 자사주매입이 소극적 투자를 야기하는 것으로 보이지 않는다. 오히려 자사주매입 실시기업은 평균적인 상장기업 또는 미실시기업에 비해 적극적 투자 성향을 나타내고 있다. 이는 자사주매입 실시기업의 총자산 성장률과 기업가치가 높은 관측과 일관된 것이다.

(5) 자사주매입은 (배당과 비교해) 기업가치가 높을수록 그 규모가 높아지는 경향이 있으며, 배당지급은 (자사주매입과 비교해) 현금흐름이 좋거나 재무적 성숙도가 높을수록 그 규모가 높아지며 주가변동성이 높을수록 그 규모가 작아지는 경향이 있다. 대주주지분율이 낮은(높은) 기업은 자사주매입(배당)을 지급수단으로 선호하는 경향이 있다.

(6) 저평가된 기업이 자사주매입을 실시한다는 주가저평가가설은 지지되지 않았다. 오히려 기업가치가 높은 기업이 자사주매입을 실시한다는 증거가 강하게 나타났다.1) 부채비율을 높이기 위한 수단으로 자사주매입을 실시한다는 레버리지가설 또한 지지되지 않았다. 현금흐름을 꾸준히 창출하고 총자산 성장률이 높은 기업일수록 자사주매입 규모가 큰 것으로 보아 일시적 현금흐름을 자사주매입으로 지급한다는 가설도 설명력이 높지 않아 보인다.

본 논문의 구성은 다음과 같다. 제 1 장의 서론에 이어 제 2 장에서는 관련 선행연구를 살펴본다. 제 3 장은 자료, 주요 변수, 분석모형을 기술한다. 제 4장은 실증분석 결과를 보고·해석한다. 제 5장에서는 논문의 한계를 서술하고 향후 연구방향을 제시한다.

\section{2. 관련 선행연구}

\section{1 미국의 선행연구}

미국의 선행연구들은 다양한 동기에 의해 자사주매입이 실시될 수 있음을 시사하는 여러 가설을 제기하였다. 이 중 주가저평가가설은 기업가치가 저평가되었을 때 자기주식을 매입한다는 주장이며, 레버리지가설은 부채비율을 높이기 위한 수단으로 자사주매입을 실시한다는 주장이다 (Stephens and Weisbach, 1998; Dittmar, 2000; Bonaimé et al., 2014). 일시적 현금흐름가설과 여유현금흐름가설은 기업이 자사주매입을 통해 일시적 현금흐름 또는 여유현금을 주주에게 지급한다고 가정한다(Dittmar, 2000; Guay and Harford, 2000; Jagannathan et al., 2000;

1) El Ghoul et al.(2020), Lee et al.(2020a, 2020b)의 최근 연구에 의하면 1990년대 이후의 기간에 대해서는 미국기업의 자사주매입-기업가치 $(\mathrm{M} / \mathrm{B}$ 비율) 간 양 $(+)$ 의 관계가 관찰되어 과거 선행연구와는 달리 미국기업들에 대해서도 주가저평가가설이 지지되지 않는다. 
한국증권학회지 제49권 5 호 (2020)

Lee and Suh, 2011). 이외에도 스톡옵션 부여 기업의 자사주매입 실시 경향이 높다(Fenn and Liang, 2001), 애널리스트 이익예측치를 달성하기 위한 수단으로 자사주매입을 실시한다 (Hribar et al., 2006), 합병에 대한 방어수단으로 자사주매입을 실시한다(Billett and Xue, 2007; Bargeron et al., 2017) 등의 가설이 연구되었다. 또한 경영자의 자기과신이 자사주매입 결정으로 이어진다는 연구도 있다(Chen and Wang, 2012).

그런데 Lee and Suh(2011) 등의 연구에 의하면 자사주매입을 활발하게 실시하는 미국기업 들과는 달리 미국 이외의 주요 선진국 기업들은 전통적인 지급수단인 배당을 주된 현금보상 정책으로 사용하고 있는 것으로 보인다.

\section{2 국내 선행연구}

앞서 서론에서 서술하였듯이 그간 국내 선행연구는 현금흐름표 상의 연도별 자사주매입금액을 사용해 분석을 할 수 없었기 때문에 자사주매입 건별 공시자료를 사용하여 자사주매입금액과 실시여부를 가늠해 분석해 왔다. 하지만 Byun(2004) 등에 의해 알려진 데로 허위공시의 문제로 자사주매입 공시규모와 실제 실적규모와는 큰 괴리가 있을 수 있으며 또한 공시기업이 자사주매입 활동을 공시한 후 매도나 소각은 제대로 공시하지 않을 경우 연도별 순매입 규모를 제대로 파악할 수 없다는 문제가 있다.

공시자료를 이용해 분석한 국내 선행연구는 주가저평가가설 등의 가설을 분석하였다. $\mathrm{Kim}$ (2003)은 1997 1999년 기간 총 173 개의 자사주매입 공시 건을 분석하여 공시 이후의 누적비정상 수익률이 유의한 양 $(+)$ 을 값을 보이며 주가저평가가설과 일관된 결과라고 해석하였다. Choi et al.(2011)은 2000 2006년 기간에 대해 자사주매입실시 계획을 공시한 기업과 비공시기업을 비교분석하여 공시기업의 공시 전후 주가수익률이 유의적으로 높음을 보고하였으며 또한 재량적 발생액이 크다고 보고한다. 한편 Jung and Lee(2003)는 1994 1998년 기간에 대해 자사주매입을 공시한 기업의 장기성과를 분석하였는데 유의한 양 $(+)$ 의 장기성과가 나타나지는 않는다는 결론을 내렸다. 그리고 Kim and Jung(2008)은 2000 2006년 기간에 대해 자사주매입을 직접취득한 기업에 비해 간접취득 기업이 공시 목표취득비율보다 상당히 낮은 실제취득비율을 나타낸다는 등의 결과를 보고하였다.

국내 선행연구 중 Lee and Joo(2005)는 1994 2002년 기간에 대해 Dittmar(2000)의 Tobit 회귀식을 추정하여 자사주매입 동기를 밝히고자 하였는데, 이 연구 역시 자사주매입 공시 자료를 기초로 자사주매입 규모변수를 생성하였다. 이 저자들은 기업규모가 클수록 여유현금흐름이 클수록 자사주매입규모가 커진다는 증거를 발견하였지만, $\mathrm{M} / \mathrm{B}$ 비율로 측정한 기업가치와 자사주 매입규모 간에는 일관된 관계를 발견하지 못해 주가저평가가설의 증거를 발견하지 못하였다. 이 밖에 Lee and Choi(2010)는 보유자사주가 있는 기업인가 아닌가의 여부로 자사주매입 실시기업 vs. 미실시기업을 식별하여 기업특성을 비교 분석하였다.

Ko and Joh(2009)는 한국거래소 공시시스템의 자사주매입 자료를 사용해 1998 2005년 기간에 대해 분석한 후 지배주주의 지분율과 자사주매입과는 음(-)의 관계가 있다고 보고한다. $\operatorname{Park}(2011)$ 도 위 공시시스템을 이용해 1999 2008년 기간 자사주매입실시 더미변수와 배당지급 
Korean Firms' Share Repurchase Activities

더미변수를 구축한 후 자사주매입기업의 최대주주지분율이 배당지급기업의 최대주주지분율보다 낮음을 보고한다. 한편 Kim and Yoon(2010)은 2004 2006년 기간 대기업집단 소속기업을 대상으로 위 공시시스템에서 구한 자료를 바탕으로 자사주매입과 소유지배괴리도 간의 관계를 분석하였다.

Byun(2004)은 1994 2000년 기간 자사주매입 공시에 대한 분석을 실시하여 주가저평가를 자사주매입 동기로 내세운 공시 기업 중 허위 공시기업의 장기성과는 음(-)의 초과 수익률을 나타낸다고 보고하였다. Byun and Pyo(2006)는 1999 2001년 기간 주가저평가를 자사주매입 동기로 공시한 기업 중 $35 \%$ 에 달하는 기업의 대주주가 공시 후 보유주식 매도를 하는 것으로 나타나 자사주매입 실시기업의 대주주가 기회주의적 행동을 한다는 증거를 제시하였다. Lim and Park(2018)은 자사주매입 취득단가 자료를 바탕으로 경영자의 마켓타이밍 능력을 분석 하였는데 실시기업의 자사주취득 단가는 공시일 이전과 취득 완료일 이후의 시장가격보다 낮기 때문에 경영자의 마켓타이밍 능력이 있다고 판단하였다. 한편 Kim and $\operatorname{Lim}(2017)$ 은 자사주의 처분(재매각) 또는 소각 의사결정을 분석하였는데 국내 기업은 소각보다는 재매각 경향이 더 높음을 보고하였다. 특히 이 연구는 자사주매입 공시 자료에 의존하지 않고 TS2000 데이터 베이스의 자기주식수와 취득자기주식수, 기말자기주식수를 사용해 자사주 처분 규모를 측정하였다.

\section{3. 표본 구축과 변수 생성}

\section{1 표본 구축}

본 연구는 유가증권시장 소속기업의 자사주매입 활동을 분석한다.2) 표본의 시작연도는 2006년인데 이는 논문작성 현재 FnGuide 데이터베이스에서 현금흐름표상 유효한 자사주 취득-처분 금액을 구할 수 있는 최초 연도가 2006년이기 때문이다.3) 표본의 마지막 연도는

2) 자사주매입에 관한 다수의 선행연구는 유가증권시장 소속기업에 한정하여 분석하였는데, 그 예로 Byun(2004), Lee and Joo(2005), Kim and Lim(2017), Lim and Park(2018), Kim and Kim(2019) 등을 들 수 있다. 본 논문의 <부록 3>에서는 2006 2016년 기간에 대해 코스닥시장 소속기업의 자사주매입 현황을 유가증권시장 소속기업과 함께 보고하였다. 패널 $\mathrm{A}$ 에 보고된 것처럼, 자사주매입을 실시한 코스닥시장 소속기업의 평균 자사주매입 규모는 유가증권시장 상장기업에 비해 작다. 예를 들어, 자사주 순매입금액의 평균(중간값)은 유가증권시장 기업의 경우 374.95억 원(17.34억 원)인 데 반해, 코스닥 소속기업은 20.10 억 원(7.60억 원)으로 작은 편이다. 패널 $\mathrm{B}$ 에서는 코스닥 소속기업에 대해 자사주매입 실시기업과 미실시기업 간의 기업특성 차이를 비교하였는데, 실시기업은 미실시 기업에 비해 기업규모가 크고, $\mathrm{M} / \mathrm{B}$ 비율이 높고, 총자산 증가율이 높으며, 현금흐름은 풍부한 것으로 나타나 본 연구가 보고하는 유가증권시장 소속기업에 대한 분석 결과와 유사한 패턴을 나타낸다.

3) 논문 작성 현재 시점에 저자들이 확인한 바에 따르면 FnGuide 데이터베이스에서 제공하는 자기주식의 취득 및 처분에 대한 자료는 2006년부터 유효한 것으로 나타났다. 즉 2005년 이전 년도에 대해서는 극히 소수의 기업을 제외하고는 자기주식 취득 및 처분 수치가 결측치를 나타내었다. 이는 논문 작성 현재 데이터베이스 회사 측의 backfilling 작업이 2006년까지만 완료되었기 때문으로 이해된다. 저자들은 2006년도 이후의 기간에 대해 무작위로 기업을 추출하여 FnGuide 데이터베이스에서 구한 자기주식 취득·처분 수치와 기업이 발표한 연차 사업보고서의 실제 현금흐름표 상의 수치와 일치함을 확인하였다. 
한국증권학회지 제49권 5호 (2020)

2016년이지만 자사주매입 실시기업의 향후 2년간 재무특질의 변화를 분석하기 때문에 실제 분석에는 2018년까지의 재무특질이 포함되었다.

기업이 자사주매입을 실시하였는지를 판단하기 위해 현금흐름표 상 자기주식 취득금액 (1001330600)과 자기주식 처분금액(1001330260)의 차이를 구해 순매입금액을 계산한 후 이 값이 양(+)의 값을 가지면 해당 연도에 자사주매입을 실시한 기업으로 분류하였다. 2006 2016년 기간에 대해 자사주매입 실시표본을 구축하는 과정은 <부록 $1>$ 에 자세히 서술하였는데, 금융회사 (산업분류코드 64-66)는 제외하였고 매출자료가 누락되거나 자본총계가 음(-)인 기업연도를 제거하였으며 또한 주가수익률, 현금흐름, 총자산, 현금비율, 부채비율, 이익잉여금비율, 주가 변동성, 배당 규모를 구할 수 없는 기업연도도 제외하였다. 최종적으로 구축한 자사주매입 표본은 2006 2016년 기간에 대해 총 1,071 개의 기업-연도 관측치(396개의 고유기업 관측치)로 구성 되었다.

아래 서술될 실증분석에서는 자사주매입 실시기업의 기업특질 등을 유가증권시장 소속 전체기업 또는 미실시기업과 비교 분석하였는데 비교 표본인 유가증권시장 소속 전체기업 또는 미실시기업도 <부록 $1>$ 에서와 같이 금융회사를 제외하는 등의 절차를 거쳤다.

\section{2 주요 변수의 정의와 생성 방법}

자사주매입 규모를 측정하는 변수로는 당해연도의 자사주매입 규모를 나타내는 자사주매입 /총자산 $\mathrm{t}_{-1}$ 과 3 년 누적 자사주매입 규모(t=0 to 2)를 측정하는 $\sum$ 자사주매입 $(\mathrm{t}, \mathrm{t}+2) /$ 총자산 $\mathrm{t}-1$ 을 사용한다. 두 변수의 분자인 자사주매입 금액은 자기주식 취득금액과 처분금액의 차이인 순매입 금액을 사용하였다. 당해연도 자사주매입 규모 이외에 추가로 3년 누적 자사주매입 규모를 고려하는 이유는 아래 <표 2>에 보고되듯이 상당히 많은 수의 기업들이 1 년 단발성이 아닌 수년간 연속적으로 자사주매입을 실시하고 있기 때문인데 연속 실시하는 기업들은 다년간 지급 계획 수립 후 순차적으로 자사주매입을 실시하는 것으로 추측된다.

분석에 사용되는 변수의 생성은 원칙적으로 별도(또는 개별)재무제표의 수치를 사용하였다. 예를 들어 자사주매입 규모 변수 구축에 필요한 자사주 순매입금액은 별도(또는 개별)재무제표 상 수치이며 연결재무제표 상 수치가 아니다. 또한 자사주매입 규모 변수는 t-1년 총자산-즉 직전년도 말 총자산-으로 표준화하였는데 총자산 또한 별도(또는 개별)재무제표 상 수치이다.4) 기업특성 변수로 사용되는 기업규모와 수익성 변수 등도 원칙적으로 개별(또는 별도)재무제표 기준으로 구축하였다. 단 예외로 $\mathrm{M} / \mathrm{B}$ 비율(총자산의 시장/장부가치)의 분모인 총자산의 장부 가치는 연결재무제표 상 수치를 사용하였는데 이는 분자인 시장가치가 종속회사의 사업가치를 반영하므로 분모-분자 간 개념적 일관성을 유지하기 위함이다.

4) 자사주매입 규모 변수 생성시 시가총액으로 나누어 표준화하는 방법도 생각할 수 있겠으나 시가총액은 변동성이 심해 자사주매입 규모 변수가 불안정해지는 문제가 있다. 또한 주가하락에 대응하는 방편으로 자사주매입을 실시하는 기업의 경우에는 낮아진 시가총액으로 인해 자사주매입 $/$ 시가총액 $\mathrm{t}_{-1}$ 변수는 높게 측정되는 반면, 반대로 향후 뛰어난 현금흐름 창출이 기대되는 기업의 자사주매입의 경우는 이 변수가 낮게 측정될 우려가 있다. 
Korean Firms' Share Repurchase Activities

기업특성을 나타내는 변수로서 $\mathrm{M} / \mathrm{B}$ 비율, 주가수익률, $\log$ (총자산), 현금비율, 부채비율, 이익잉여금비율, 주가변동성과 함께 배당-총자산 비율(=배당/총자산)을 사용하였는데 각 변수의 정의는 <부록 $2>$ 에 정리되어 있다. 모든 기업특성 변수는 직전년도 말 기준으로 계산되었다. 모든 연속변수는 분포의 상하위 $1 \%$ 에서 원저라이즈하였다.

\section{4. 실증분석 결과}

\section{1 표본기업의 자사주매입 현황}

$<$ 표 1>은 자사주매입 실시 표본에 포함된 관측치 수와 자사주 매입규모(자사주 매입금액, 처분금액 및 순매입금액)를 보고한다. 연도별 자사주매입 실시기업의 수는 최소 69건(2006년) 부터 최대 159건(2008년)까지 분포하고 있는데 총 관측치 수는 1,071 건이다. 자사주매입 규모를 순매입금액 $=$ 자사주 취득금액-자사주 처분금액)으로 측정하자면, 표본기업의 자사주매입은 평균 374.95억 원으로 높지만 중간값은 17.34 억 원으로 우측 왜도가 높은 분포를 나타낸다. 순매입금액의 평균은 연도별로 편차가 높은 편인데 2016년에는 평균 1,017.05억 원이었지만 2013년에는 평균 74.84억 원을 기록하였다.

<표 2>는 표본기업에 대해 자사주매입의 연속성과 그 규모를 연도별로 보고한다. 패널 $\mathrm{A}$ 에서는 자사주매입의 연속성을 파악하기 위해, 당해연도 $(\mathrm{t}=0)$ 에 자사주매입을 실시한 기업이 다음 해(2년 연속) 및 그 다음 해(3년 연속) 연속적으로 실시하는 기업의 비중을 계산하였다. 자사주매입 표본(1,071건) 중 2 년 연속 실시기업 비율(즉, $\mathrm{t}=0$ 과 $\mathrm{t}=1$ 모두 실시하는 기업의 비중)은 $52.5 \%$ 로 나타나 표본기업의 절반 이상이 그 다음해에도 자사주매입을 실시하는 것으로 나타났으며, 3 년 연속 실시기업 비율(즉, $\mathrm{t}=0, \mathrm{t}=1, \mathrm{t}=2$ 모두 실시하는 기업의 비중)은 $31.0 \%$ 로 나타나 대략 3 분의 1 정도는 3 년 연속으로 자사주매입을 실시하는 것으로 나타났다.

패널 $\mathrm{B}$ 는 전년도 $(\mathrm{t}-1)$ 총자산 대비 당해연도 자사주매입 규모와 함께 2 년과 3 년치 누적 자사주매입 규모를 보고한다. 먼저, 당해연도 자사주매입 규모(자사주매입 $/$ 총자산 -1 )의 평균은 $1.2 \%$ (중간값 $0.5 \%$ )로 나타나, 표본기업은 전년도 총자산 대비 평균 $1.2 \%$ 수준의 자사주매입을 실시하는 것을 알 수 있다. 그리고 2 년 누적 자사주매입 규모 $\left(\sum\right.$ 자사주매입 $(t, t+1) /$ 총자산 $\left.t_{-1}\right)$ 의 평균은 $1.7 \%$ (중간값 $0.8 \%$ )로, 3 년 누적 자사주매입 규모( $\sum$ 자사주매입 $(\mathrm{t}, \mathrm{t}+2) /$ 총자산 $\left.\mathrm{t}-1\right)$ 의 평균은 $2.0 \%$ (중간값 $0.9 \%$ )로 각각 나타났다.

\section{2 자사주매입 실시 vs. 미실시기업에 대한 단변량 비교 분석}

$<$ 표 3>에서는 자사주매입 실시기업의 주요 재무적 특성치의 평균과 중간값을 자사주매입 미실시기업과 비교하여 분석한다. 미실시기업은 유가증권시장 소속기업 중 당해연도 자사주 순매입액이 0 또는 음(-)인 기업이다. 마지막 칼럼에선 실시기업과 미실시기업의 평균과 중간값이 통계적으로 유의적인 차이를 나타내는지 검증한 결과를 보고한다.

자사주매입 실시기업의 기업규모 $(\log$ (총자산) )는 평균 26.800(중간값 26.573)으로 미실시 기업의 평균 26.592(중간값 26.311)보다 유의적으로 높아 실시기업이 미실시기업보다 상대적으로 


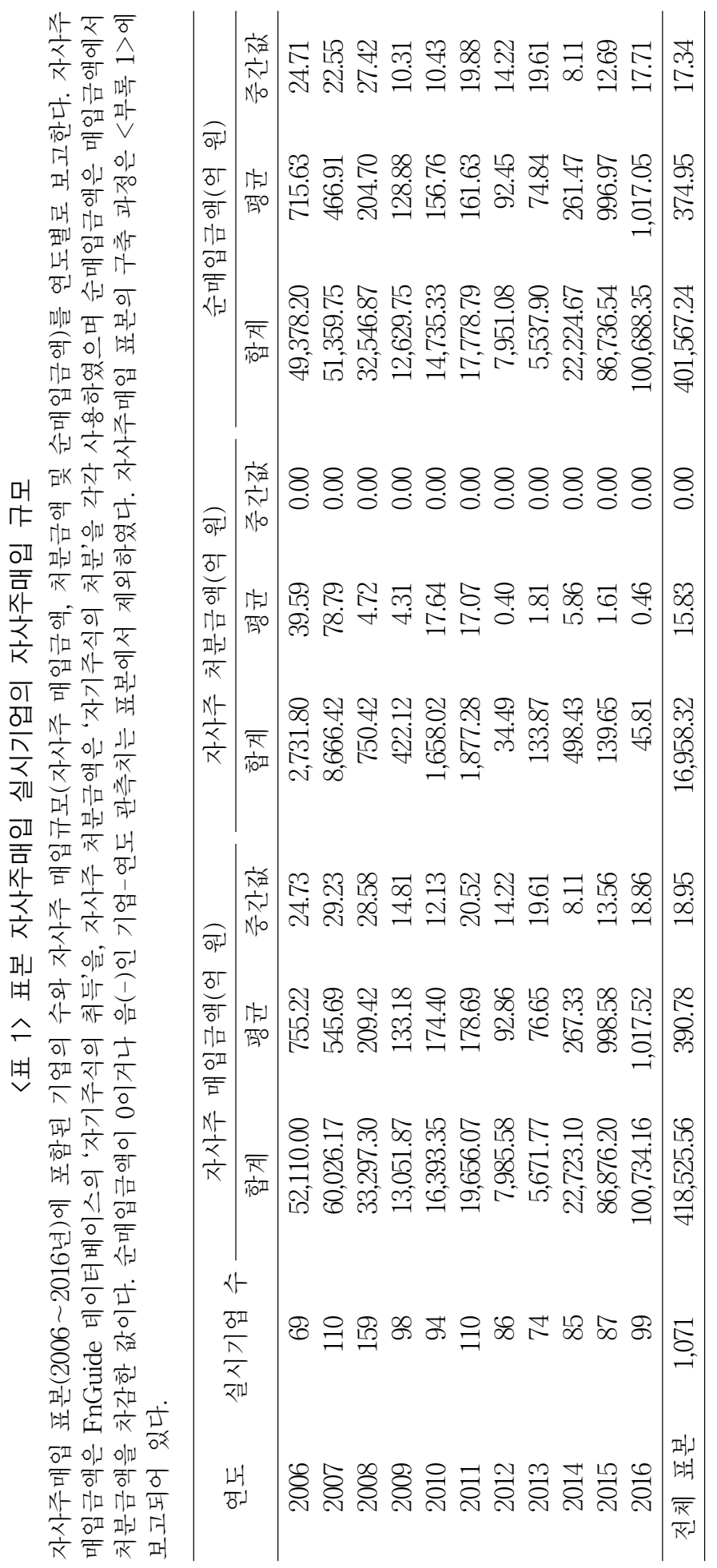


Korean Firms' Share Repurchase Activities

〈표 2〉 표본기업의 자사주매입 빈도, 연속성, 규모

자사주매입 표본(2006 2016년 기간)에 포함된 기업의 자사주매입 실시 연속성, 규모를 보고한다. 패널 $\mathrm{A}$ 의 “2년 연속 실시기업 비율”은 당해연도(즉 $\mathrm{t}=0$ ) 자사주매입 실시기업 중 2 년 연속 실시(즉, $\mathrm{t}=0$ 과 $\mathrm{t}=1$ 모두 실시)하는 기업의 비중을 나타나며 “3년 연속 실시기업 비율” 은 당해연도 자사주매입 실시기업 중 3 년 연속 실시(즉, $\mathrm{t}=0, \mathrm{t}=1, \mathrm{t}=2$ 모두 실시)하는 기업의 비중을 나타낸다. 패널 $\mathrm{B}$ 는 당해연도 자사주매입 규모와 함께 2년과 3년치 누적 규모를 보고한다. 자사주매입 규모는 순매입금액이며 2년치 누적은 $\mathrm{t}=0$ 과 $\mathrm{t}=1$ 합계금액, 3 년치 누적은 $\mathrm{t}=0, \mathrm{t}=1, \mathrm{t}=2$ 의 합계 금액이다. 모두 $\mathrm{t}-1$ 의 연말 총자산으로 나누어 표준화하였으며 각각 자사주매입 $/$ 총자산 $\mathrm{t}_{-1}, \sum$ 자사주매입(t,t+1)/총자산 $\mathrm{t}-1, \sum$ 자사주매입(t,t+2)/ 총자산 $\mathrm{t}_{-1}$ 으로 명명되었다.

패널 A: 자사주매입 실시기업 수와 실시 연속성

\begin{tabular}{cccc}
\hline 연도 & 실시기업 수 & 2년 연속 실시기업 비율 & 3년 연속 실시기업 비율 \\
\hline 2006 & 69 & 0.522 & 0.362 \\
2007 & 110 & 0.645 & 0.282 \\
2008 & 159 & 0.465 & 0.277 \\
2009 & 98 & 0.531 & 0.357 \\
2010 & 94 & 0.543 & 0.255 \\
2011 & 110 & 0.418 & 0.209 \\
2012 & 86 & 0.465 & 0.291 \\
2013 & 74 & 0.608 & 0.365 \\
2014 & 85 & 0.518 & 0.365 \\
2015 & 87 & 0.563 & 0.356 \\
2016 & 99 & 0.545 & 0.364 \\
\hline 전체 표본 & 1,071 & 0.525 & 0.310 \\
\hline
\end{tabular}

패널 B: 자사주 매입기업의 당해연도, 2 년 누적, 3 년 누적 실시규모

\begin{tabular}{|c|c|c|c|c|}
\hline & & 당해연도 규모 & 2년 누적 규모 & 3년 누적 규모 \\
\hline & & 자사주매입 $t$ 총자산 $t-1$ & $\begin{array}{c}\sum \text { 자사주매입 }(\mathrm{t}, \mathrm{t}+1) \\
\text { /총자산 } \mathrm{t}-1\end{array}$ & $\begin{array}{c}\sum \text { 자사주매입 }(\mathrm{t}, \mathrm{t}+2) \\
\text { /총자산 }_{\mathrm{t}-1}\end{array}$ \\
\hline 연도 & 실시기업 수 & 평균[중간값] & 평균[중간값] & 평균[중간값] \\
\hline 2006 & 69 & $0.017[0.012]$ & $0.025[0.015]$ & $0.033[0.021]$ \\
\hline 2007 & 110 & $0.014[0.009]$ & $0.026[0.014]$ & $0.029[0.014]$ \\
\hline 2008 & 159 & $0.017[0.011]$ & $0.019[0.011]$ & $0.019[0.010]$ \\
\hline 2009 & 98 & $0.009[0.003]$ & $0.013[0.006]$ & $0.018[0.006]$ \\
\hline 2010 & 94 & $0.010[0.005]$ & $0.016[0.009]$ & $0.018[0.008]$ \\
\hline 2011 & 110 & $0.011[0.005]$ & $0.011[0.005]$ & $0.013[0.005]$ \\
\hline 2012 & 86 & $0.011[0.004]$ & $0.016[0.003]$ & $0.015[0.003]$ \\
\hline 2013 & 74 & $0.010[0.006]$ & $0.012[0.008]$ & $0.019[0.009]$ \\
\hline 2014 & 85 & $0.007[0.002]$ & $0.012[0.005]$ & $0.017[0.006]$ \\
\hline 2015 & 87 & $0.010[0.004]$ & $0.016[0.007]$ & $0.021[0.009]$ \\
\hline 2016 & 99 & $0.011[0.005]$ & $0.018[0.009]$ & $0.024[0.011]$ \\
\hline 전체 표본 & 1,071 & $0.012[0.005]$ & $0.017[0.008]$ & $0.020[0.009]$ \\
\hline
\end{tabular}




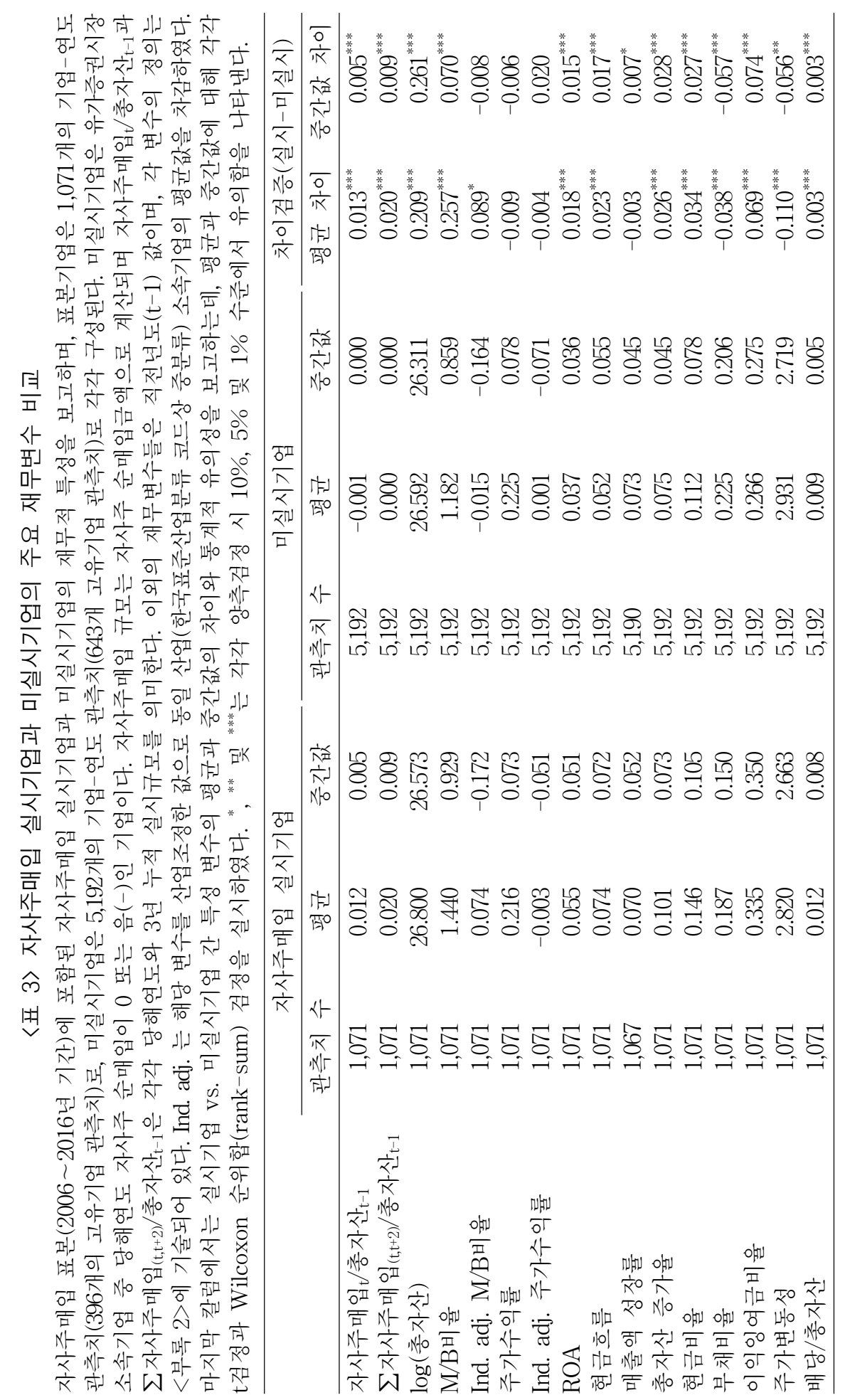


Korean Firms' Share Repurchase Activities

기업규모가 큰 것으로 나타났다. 기업가치를 나타내는 $\mathrm{M} / \mathrm{B}$ 비율은 실시기업이 평균 1.440 (중간값 0.929)으로서 미실시기업의 평균 1.182 (중간값 0.859)보다 유의적으로 높아 자사주매입 기업의 기업가치가 상대적으로 높음을 알 수 있다. 직전년도 주가수익률의 평균값(중간값)은 실시기업이 $21.6 \%(7.3 \%)$, 미실시기업이 $22.5 \%(7.8 \%)$ 로 나타났는데, 두 집단 간의 통계적인 차이는 없었다. 또한 산업평균 주가수익률을 차감하여 계산한 산업조정 주가수익률(Ind. adj. 주가수익률) 역시 실시기업과 미실시기업 간 유의한 차이가 나타나지 않았다. 이처럼 자사주매입 실시기업의 기업가치가 높으며 직전년도 주가수익률이 미실시기업과 유의적 차이를 나타내지 않는 관측은 주가저평가가 자사주매입 동기라는 가설을 지지하지는 않는다.

수익성을 나타내는 변수인 ROA는 실시기업이 평균 5.5\%(중간값 $5.1 \%$ )로서 미실시기업의 평균 3.7\%(중간값 $3.6 \%$ )보다 유의적으로 높으며, 현금흐름 또한 실시기업이 평균 $7.4 \%$ (중간값 $7.2 \%$ )로서 미실시기업의 평균 5.2\%(중간값 5.5\%)보다 유의적으로 크게 나타났다. 그리고 총자산 대비 이익잉여금으로 측정한 이익잉여금비율은 실시기업이 평균 $33.5 \%$ (중간값 $35.0 \%$ )로서 미실시기업의 평균 $26.6 \%$ (중간값 $27.5 \%$ )보다 유의적으로 크게 나타났다. 이외에도 실시기업의 총자산 증가율, 현금비율, 배당-총자산 비율은 미실시기업보다 유의적으로 높은 반면, 실시기업의 부채비율과 주가변동성은 미실시기업보다 유의적으로 낮게 나타났다.

이상 자사주매입 실시기업과 미실시기업의 재무적 특성에 대한 분석결과를 요약하면, 자사주 매입 실시기업은 미실시기업보다 기업규모가 크고 기업가치가 높으며 수익성이 우수하였다. 또한 이익잉여금비율, 총자산 증가율, 현금비율, 배당-총자산 비율이 모두 높은 반면 부채비율은 낮고 주가변동성은 작은 것으로 나타났다. 반면에 직전년도 주가수익률은 자사주매입 실시기업과 미실시기업 간에 유의한 차이가 나타나지 않았다.

\section{3 자사주매입 규모에 대한 Tobit 회귀분석}

다음 분석에서는 자사주매입 의사결정에 영향을 미치는 요인을 파악하기 위해 자사주매입 규모를 종속변수 그리고 주요 기업특성을 설명변수로 설정한 Tobit 회귀분석을 실시한다. 종속변수로는 당해연도 자사주매입 규모와 3년치 누적자사주 매입규모를 사용하였으며, 설명 변수로는 Dittmar(2000)의 회귀모형을 참조하여 기업규모 $\log$ (총자산)), M/B비율, 주가수익률, 현금흐름 등을 선정하였다.

회귀분석에 앞서 <표 $4>$ 에서는 회귀모형의 종속·설명변수에 대해 피어슨 상관계수 매트릭스를 보고한다. 종속변수로 사용되는 당해연도 자사주매입 규모(자사주매입 $t$ 총자산 $t-1$ )와 3 년 누적 자사주매입 $\left(\sum\right.$ 자사주매입 $(\mathrm{t}, \mathrm{t}+2) /$ 총자산 -1$)$ 간의 상관계수는 0.586 으로 높게 나타났다. 당해연도 자사주매입 규모는 $\mathrm{M} / \mathrm{B}$ 비율, 현금흐름, 현금비율 및 배당-총자산 비율과는 모두 $1 \%$ 수준에서 유의한 양 $(+)$ 의 관계를 가지는데 반해, 부채비율 및 주가변동성과는 모두 $1 \%$ 수준에서 유의한 음(-)의 관계를 가지는 것으로 나타났다. 3 년 누적 자사주매입 규모 또한 위 기업특성변수들과 유사한 상관관계 패턴을 나타내고 있다.

<표 5>는 Tobit 회귀식 추정 결과를 보고하는데, 패널 $\mathrm{A}$ 와 패널 $\mathrm{B}$ 의 종속변수는 각각 당해연도 자사주매입 규모, 3 년 누적 자사주매입 규모이다. 각 패널에 보고된 추정 회귀식(모형 


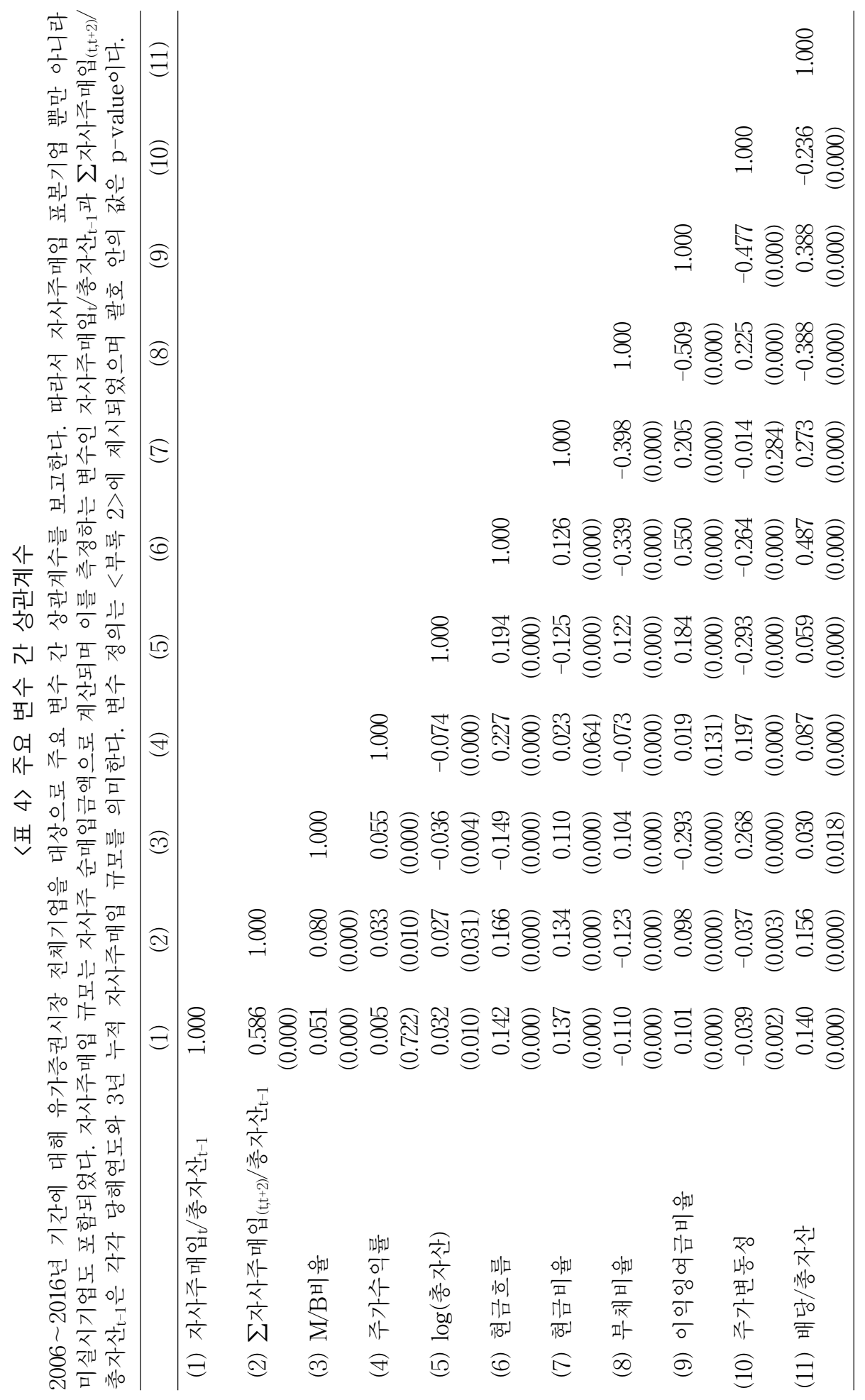


Korean Firms' Share Repurchase Activities

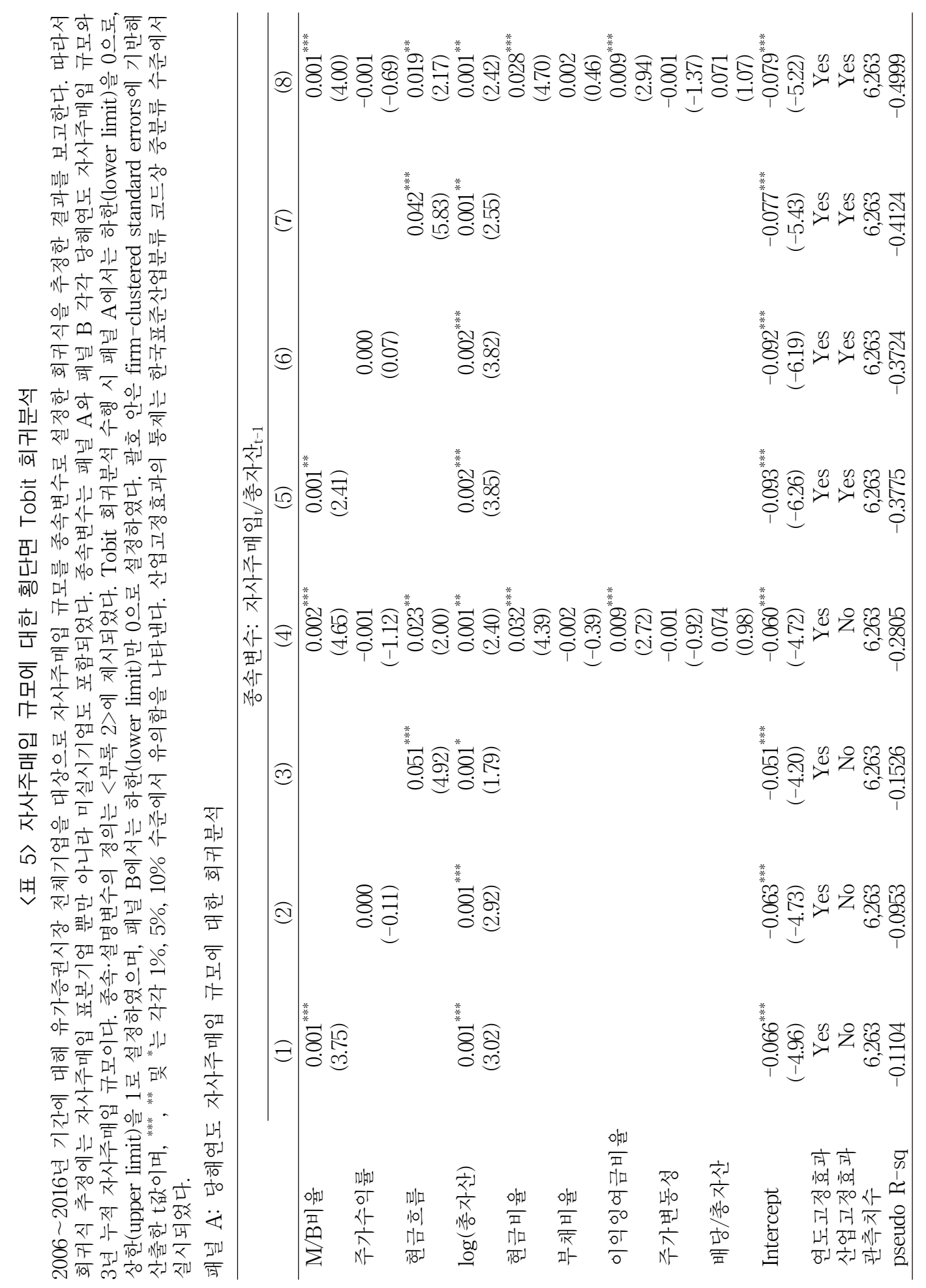




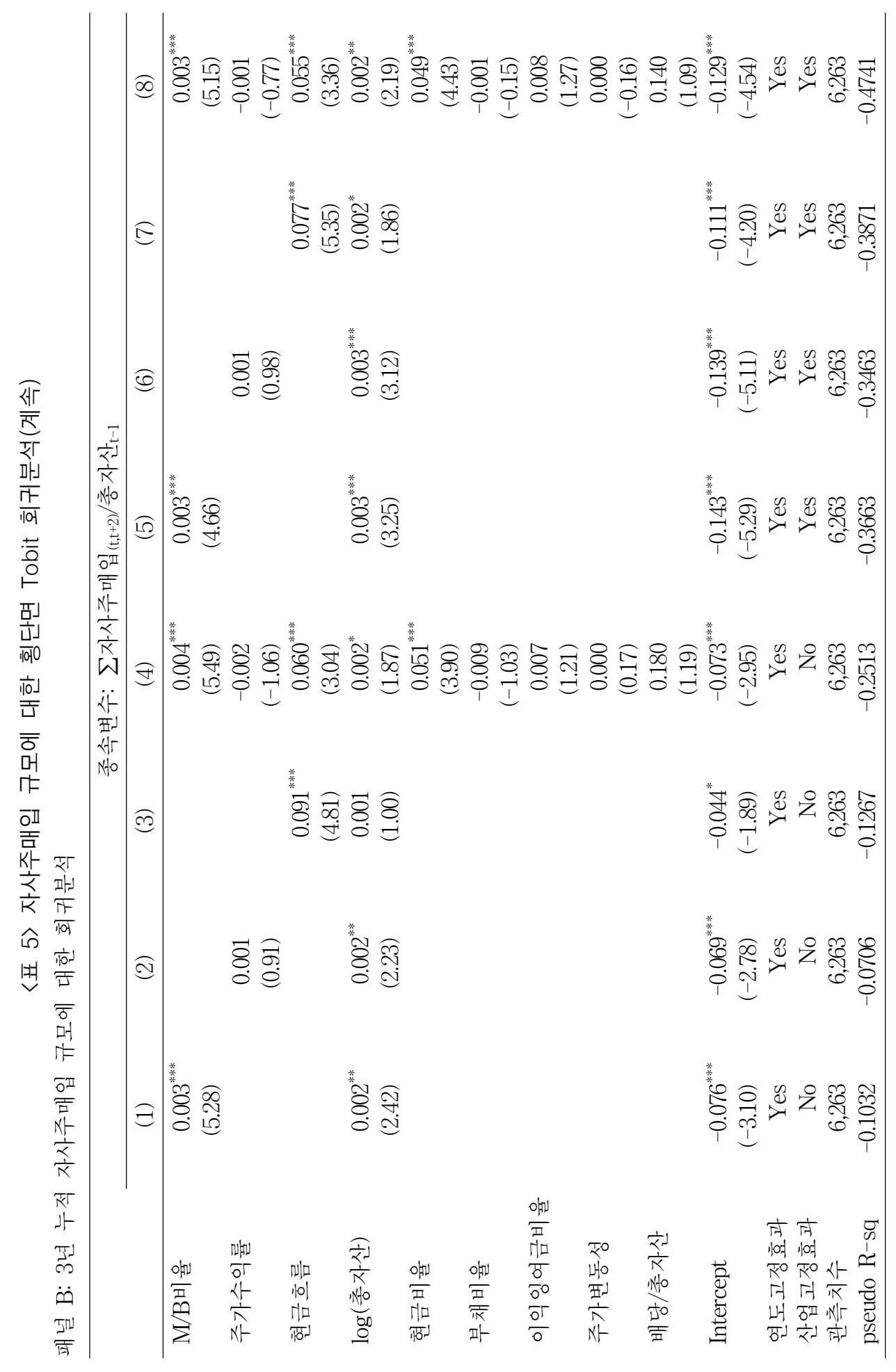


(1)-(8))은 모두 연도고정효과를 통제하였는데, 첫 번째 4개의 회귀식(모형 (1)-(4))에서는 산업고정효과를 통제하지 않은 반면, 다음 4개의 회귀식(모형 (5)-(8))에서는 산업고정효과를 통제하였다.

회귀식 추정 결과의 해석은 미국 선행연구에서 제기되고 분석된 주요 가설에 초점을 맞추고자 한다(Dittmar, 2000 등). 먼저 주가저평가가설에 따르면 기업가치가 낮거나 최근 주가실적이 안 좋은 기업일수록 자사주매입을 실시할 것이기 때문에 $\mathrm{M} / \mathrm{B}$ 비율과 직전년도 주가수익률이 자사주매입에 음(-)의 영향을 나타낼 것으로 예측한다. 현금흐름가설은 현금흐름으로 측정한 내부창출자금이 풍부한 기업일수록 그 자금을 주주보상으로 사용한다는 주장이며 현금흐름이 자사주매입에 양(+)의 영향을 나타낼 것으로 예측한다. 레버리지가설은 부채비율이 낮은 기업이 레버리지를 올리기 위한 수단으로 자사주매입을 실시한다는 주장이며 부채비율이 자사주매입에 음(-)의 영향을 나타낼 것으로 예측한다.

$<$ 표 5>의 패널 A에서 종속변수는 당해연도 자사주매입 규모(자사주매입 $/$ 총자산 $\mathrm{t}_{-1}$ )이다. 모형 (1)에서 $\mathrm{M} / \mathrm{B}$ 비율은 유의한 양(+)의 계수값을 나타내며 다른 설명변수를 추가한 모형 (4)에서도 유의한 양 $(+)$ 의 계수값을 나타낸다. 또한 산업고정효과를 통제한 모형 (5)와 (8)에서도 계속해서 유의한 양(+)의 계수값을 나타내어 기업가치는 자사주매입에 양 $(+)$ 의 영향을 미치는 것으로 나타났다. 직전년도 주가수익률을 설명변수로 사용한 모형 (2), (4), (6), (8)에서는 이 변수의 계수값이 모두 유의성을 나타내지 않았으며 따라서 주가수익률이 저조한 기업이 주가 부양을 위해 자사주매입을 실시한다는 가설은 지지되지 않았다. 한편 현금흐름을 설명변수로 포함한 모형 (3), (4), (7), (8)에서는 모두 현금흐름이 양(+)의 계수값을 나타내 현금흐름은 자사주매입에 양(+)의 영향을 미치는 것으로 나타났다. 또한 모든 회귀모형 (1)-(8)에 설명변수로 포함된 기업규모 $(\log$ (총자산 $))$ 는 예외 없이 유의한 양 $(+)$ 의 계수값을 나타내는데 이는 대기업 일수록 자사주매입을 실시하거나 실시규모가 큰 경향이 있음을 시사한다. 한편, 패널 $\mathrm{A}$ 의 모형 (4)와 (8)은 부채비율과 기타 변수들을 설명변수로 포함하는데 부채비율의 계수값은 유의성이 없었기 때문에 레버리지가설은 지지되지 않았다.

패널 $\mathrm{B}$ 는 3 년 누적 자사주매입 비율 $\left(\sum\right.$ 자사주매입(t,t+2)/총자산 $\left.\mathrm{t}-1\right)$ 을 종속변수로 설정한 추정 결과를 보고한다. 보고된 결과는 패널 $\mathrm{A}$ 의 결과와 질적으로 유사하다. $\mathrm{M} / \mathrm{B}$ 비율은 설명변수로 포함된 모든 모형에서 유의한 양(+)의 계수값을 나타내는 반면 주가수익률은 설명변수로 포함된 모든 모형에서 계수값의 유의성이 없었으며 따라서 주가저평가가설은 지지되지 않았다. 현금 흐름은 포함된 모든 회귀식에서 양(+)의 계수값을 가져 현금흐름이 좋을수록 자사주매입에 적극적이라는 앞서의 관측을 재확인시켜 주고 있다. 또한 기업규모 $(\log$ (총자산))는 모형 (3)을 제외하고는 모든 모형에서 양(+)의 계수값을 나타내어 대기업일수록 자사주매입에 적극적이라는 관측이 재확인되었으며 부채비율의 계수값은 유의성이 없어 레버리지가설은 여전히 지지되지 않았다.

\section{4 자사주매입 실시기업의 3년간 주요 성장률과 자본구조 구성요소 변화}

본 절에서는 자사주매입 실시와 동반된 재무변수의 3 년간 변화를 관찰함으로써 자사주매입의 
한국증권학회지 제49권 5호 (2020)

성격에 대해 더 면밀한 분석을 하고자 한다. 이 분석에서 초점을 두는 질문은 국내 기업들이 자사주매입에 필요한 재원을 어떻게 조달하는 것이다. 재원은 외부자금과 내부자금으로 나눌 수 있다. 외부자금의 경우 유상증자와 부채조달을 생각할 수 있으나 자사주매입을 통해 주주에게 투자자금을 환원하려는 기업이 동시에 유상증자를 실시하려는 경우는 일반적이지 않다고 본다면 부채조달을 재원으로 고려할 수 있다. 내부자금의 경우 기존 보유현금과 영업에서 창출된 현금흐름을 재원으로 생각할 수 있는데, 기존 보유현금을 자사주매입의 재원으로 사용할 경우 보유현금의 감소가 발생할 수 있다. 영업창출 현금흐름을 자사주매입의 재원으로 활용하는 경우를 회계적으로 설명하자면 다음과 같다. 먼저 현금흐름을 현금으로 보유 처리하는 과정에서 이익잉여금 증가가 발생하므로 재무상태표의 “좌변 현금 증가, 우변 이익잉여금 증가"가 일어난다. 이후 자사주매입 실시로 인해 “좌변 현금 감소, 우변 납입자본금 감소”가 일어난다. 따라서 두 단계를 합쳐 본다면, 현금흐름을 자사주매입의 재원으로 사용하는 기업은 당해연도에는 “우변 이익잉여금 증가, 우변 납입자본금 감소”가 발생한다고 볼 수 있다.5)

<표 6>은 자사주매입 표본에 대해 t-1년부터 t+2년까지 3년간 주요 변수의 변화 규모의 평균과 중간값을 보고하며 또한 3 년 누적 자사주매입 규모 $\left(\sum\right.$ 자사주매입 $(\mathrm{t}, \mathrm{t}+2) /$ 총자산 $\left.\mathrm{t}-1\right)$ 를 기준 으로 실시규모 상위기업과 하위기업으로 이등분한 후 두 그룹에 대해 각각 평균과 중간값도 보고한다. 자사주매입 표본 전체의 3년 누적 자사주매입 규모는 평균 $2.0 \%$ (중간값 $0.9 \%$ )인데, 실시규모 상위기업은 평균 $4.2 \%$ (중간값 $2.6 \%$ ), 실시규모 하위기업은 평균은 $-0.2 \%$ (중간값 $0.0 \%)$ 로 나타났다.

자사주매입 표본의 $\mathrm{t}-1 \sim \mathrm{t}+2$ 년 기간 3년 총자산 성장률의 평균은 $26.2 \%$ (중간값 $20.7 \%$ )인데, 실시규모 상위기업의 동변수 평균 $28.3 \%$ (중간값 $21.0 \%$ )는 실시규모 하위기업의 평균 $24.2 \%$ (중간값 $18.8 \%$ )보다 높게 나타나 자사주매입 규모가 클수록 총자산 성장률이 큰 것으로 보인다. 하지만 총자산 성장률과는 달리 매출액 성장률은 실시규모 상위기업이 실시규모 하위기업에 비해 평균과 중간값에서 낮은 현상을 보이고 있다.

현금흐름의 3 년간 누적규모의 경우 전체 표본은 평균 $20.8 \%$ (중간값 $18.8 \%$ )인데, 실시규모 상위기업의 평균 $27.1 \%$ (중간값 $24.9 \%$ )가 실시규모 하위기업의 평균 $14.4 \%$ (중간값 $13.8 \%$ )보다 상당히 높았기 때문에 자사주매입의 주된 재원이 현금흐름이라는 추측이 가능하다. 반면 보유현금의 3 년간 증가규모는 실시규모 상위기업의 평균 $3.4 \%$ (중간값 $0.5 \%$ )가 실시규모 하위기업의 평균 $3.1 \%$ (중간값 $1 \%$ )와 큰 차이가 없어 보유현금을 자사주매입으로 사용한다는 추측을 지지하지는 않는다. 또한 기존 보유현금을 자사주매입의 재원으로 활용할 경우 보유현금의 감소가 일어날 수도 있겠으나 관찰된 보유현금 3 년간 변화량의 평균과 중간값은 모두 양 $(+)$ 의 값을 나타내 이 예측을 지지하지 않는다.

5) 국내 자사주매입 기업 중에는 이익소각 방식으로 자사주매입 후 주식을 소각하는 경우가 있는데, 이 경우 자사주매입은 재무상태표의 “좌변 현금 감소, 우변 이익잉여금 감소”를 초래하며 납입자본금은 감소하지 않는다. 저자들은 TS2000 데이터베이스를 통해 이익소각을 실시하는 기업을 추출해 보았으나 그 수는 매우 소수인 것으로 나타났다. 
Korean Firms' Share Repurchase Activities

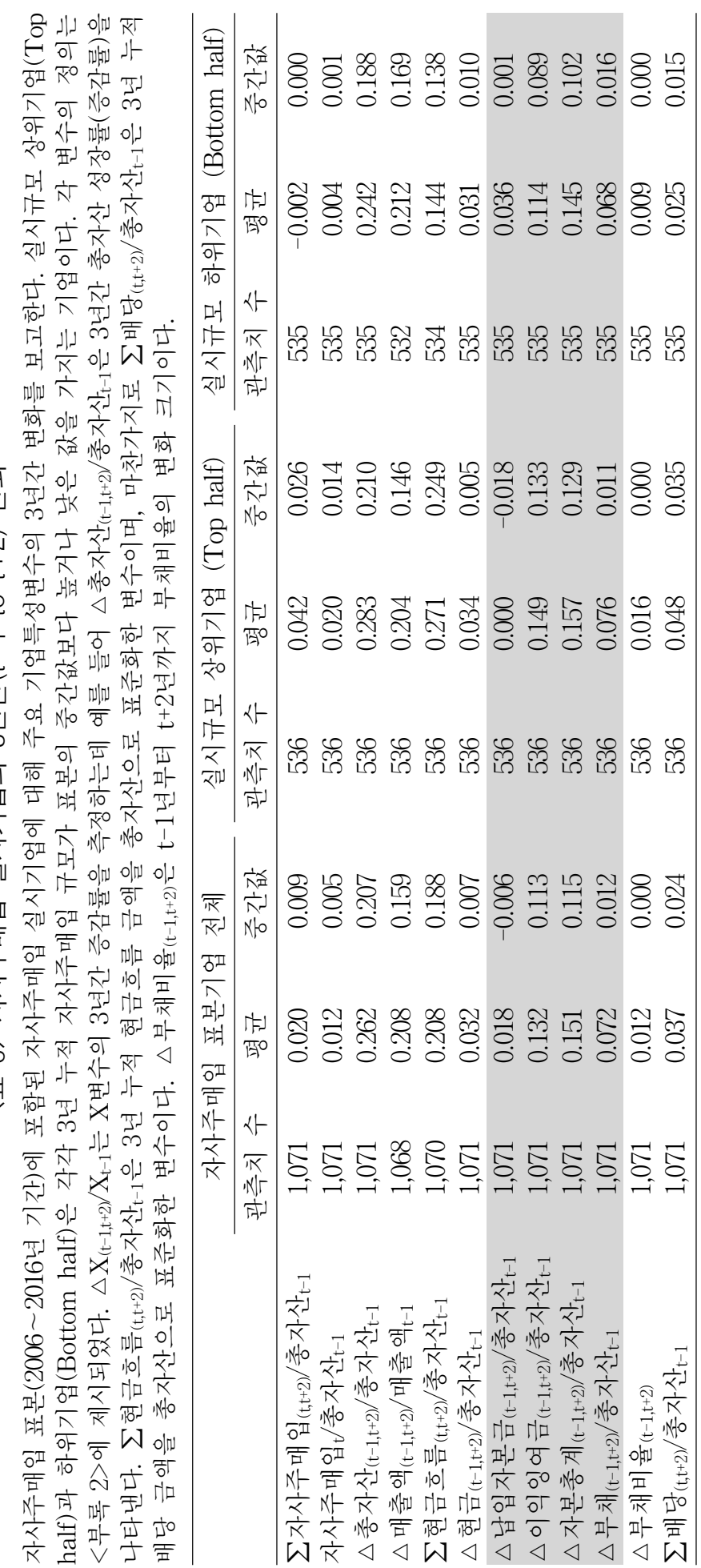


한국증권학회지 제49권 5호 (2020)

자본구조를 나타내는 비율의 변화를 살펴보자면, 납입자본금의 3년간 증가규모는 전체기업에 대해 평균 $1.8 \%$, 중간값 $-0.6 \%$ 로 나타나 중간값 기준으로는 자사주매입이 납입자본금을 감소 시키나 평균 기준으로는 납입자본금을 감소시키지는 못하는 것을 알 수 있다. 이는 자사주매입을 실시하는 기업 중 적지 않은 수가 유상증자를 실시해 납입자본금을 늘인다는 것을 의미한다. 하지만 실시규모 상위기업의 납입자본금 변화(평균 $0.0 \%$, 중간값 $-1.8 \%$ )는 실시규모 하위기업 (평균 $3.6 \%$, 중간값 $0.1 \%$ )보다 작게 나타났다.

그런데 자본구조 구성요소 중 가장 큰 변화를 보이는 구성요소는 이익잉여금이다. 이익잉여금의 3 년간 증가규모는 평균 $13.2 \%$, 중간값 $11.3 \%$ 로 부채의 3 년간 증가규모인 평균 $7.2 \%$, 중간값 $1.2 \%$ 를 휠씬 상회한다. 또한 실시규모 상위기업의 이익잉여금 증가규모(평균 $14.9 \%$, 중간값 $13.3 \%$ )는 실시규모 하위기업(평균 $11.4 \%$, 중간값 $8.9 \%$ )보다 상당히 높은 수준이여서 자사주매입 실시규모와 이익잉여금 증가 간에 밀접한 관계가 있는 것으로 보인다. 이는 앞서 자사주매입 실시기업-특히 실시규모 상위기업-의 현금흐름창출 규모가 상당히 높은 것과 일관성이 있는데, 자사주매입 실시기업은 높은 현금흐름을 창출하며 이 중 상당 부분이 이익잉여금 증가로 이어지는 것으로 보인다.

이상 관찰된 자사주매입 실시와 동반된 재무변수의 변화를 요약하고 그 시사점을 정리하자면 다음과 같다. 자사주매입은 높은 수준의 총자산 성장률과 현금흐름 창출을 동반하는데 이는 앞서 기업가치가 높은 기업이 자사주매입을 실시한다는 관측과 일관된 것이다. 또한 자사주매입 실시기업이 높은 수준의 현금흐름을 창출한다는 것은 자사주매입의 재원이 현금흐름(즉 내부창출 자금)일 가능성이 높음을 시사한다. 이 관측과 일관되게 자사주매입 실시기업의 자본구조 구성요소 중 이익잉여금의 증가가 부채 등 다른 구성요소의 변화보다 매우 크게 나타난다.6) 현금흐름이 풍부한 기업이 부채조달까지 하면서 자사주매입 재원을 마련한다고 보는 것은 비현실적이고, 자사주매입기업은 평균과 중간값 기준으로 보유현금 감소가 발생하지 않는 것으로 보아 국내 상장기업의 자사주매입의 주된 재원은 현금흐름으로 판단된다.

$<$ 표 7>에서는 추가 분석을 통해 자사주매입의 재원을 추론한다. 패널A는 자사주매입 표본 전체를 대상으로 $\mathrm{t}-1$ 년부터 $\mathrm{t}+2$ 년까지 기말 자본구조 구성비율과 현금비율의 평균과 중간값을 보고한다. 가장 눈에 띄는 패턴은 $\mathrm{t}-1$ 년부터 $\mathrm{t}+2$ 년까지 이익잉여금비율(즉, 이익잉여금-총자산 비율)은 꾸준히 상승하지만 납입자본금비율(즉, 납입자본금-총자산 비율)은 반대로 꾸준히 하락한다는 것이다. 예를 들어 이익잉여금비율의 평균(중간값)은 t-1년 0.335(0.350)에서 t+2년 $0.366(0.389)$ 으로 3 년간 약 $3.1 \% \mathrm{p}(3.9 \% \mathrm{p})$ 상승한다. 반면, 납입자본금비율의 평균(중간값)은 $\mathrm{t}-1$ 년 $0.244(0.201)$ 에서 $\mathrm{t}+2$ 년 $0.228(0.164)$ 로 3 년간 약 $1.6 \% \mathrm{p}(3.7 \% \mathrm{p})$ 하락한다. 이는 앞서

6) 국내 기업의 자사주매입 규모는 미국기업의 자사주매입 규모에 비해 현저하게 작은 수준이기 때문에 자사주매입의 재원이 현금흐름창출을 통한 내부유보인지 부채조달인지 기존 보유현금인지 가늠하기 쉽지는 않다. 미국기업의 자사주매입 행태를 분석한 최근 연구인 El Ghoul et al.(2020)에 의하면 자사주매입 규모 상위기업의 자사주매입 규모와 이익잉여금의 증가 규모는 평균 면에서 매우 비슷한 수준인데, 이는 자사주매입 실시기업들이 영업으로 창출된 이익을 내부유보(따라서 회계상 이익잉여금 증가)하면서 이를 동년 자사주매입으로 지급하는 것으로 해석할 수 있다고 한다. 
Korean Firms' Share Repurchase Activities

<표 6>이 시사하듯이 자사주매입의 주 재원은 내부창출현금흐름, 즉 이익잉여금이라는 추측을 뒷받침하는 것이다. 반면 부채비율과 현금비율의 변화 크기는 상대적으로 작다. 부채비율의

〈표 7〉 자사주매입 표본기업의 자본구조 변화 $(\mathrm{t}-1$ to $\mathrm{t}+2)$

패널 A는 자사주매입 표본(2006 2016년 기간)에 포함된 자사주매입 실시기업에 대해 $\mathrm{t}-1$ 년부터 $\mathrm{t}+2$ 년까지 자본구조의 구성요인인 납입자본금비율, 이익잉여금비율, 자본총계비율, 부채비율과 함께 현금비율의 연도별 평균과 중간값을 보고한다. 각 비율은 해당 변수를 총자산으로 나누어 계산(회계년도말 기준) 되었으며 구체적인 정의는 <부록 $2>$ 에 제시되었다. $\mathrm{t}$ 는 자사주매입이 관측된 년도이다. 패널 $\mathrm{B}$ 는 비율 대신 절대금액(단위: 억 원)을 사용하여 연도별 평균과 중간값을 보고한다.

패널 $\mathrm{A}$ : 비율의 추세

\begin{tabular}{lllccc}
\hline & & $\mathrm{t}-1$ & $\mathrm{t}$ & $\mathrm{t}+1$ & $\mathrm{t}+2$ \\
\hline 납입자본금비율 & 관측치 수 & 1,071 & 1,071 & 1,070 & 1,071 \\
& 평균 & 0.244 & 0.246 & 0.228 & 0.228 \\
& 중간값 & 0.201 & 0.183 & 0.171 & 0.164 \\
이익잉여금비율 & 관측치 수 & 1,071 & 1,071 & 1,070 & 1,071 \\
& 평균 & 0.335 & 0.352 & 0.360 & 0.366 \\
& 중간값 & 0.350 & 0.373 & 0.379 & 0.389 \\
자본총계비율 & 관측치 수 & 1,071 & 1,071 & 1,070 & 1,071 \\
& 평균 & 0.597 & 0.600 & 0.601 & 0.602 \\
& 중간값 & 0.607 & 0.610 & 0.611 & 0.614 \\
부채비율 & 관측치 수 & 1,071 & 1,071 & 1,070 & 1,071 \\
& 평균 & 0.187 & 0.192 & 0.196 & 0.199 \\
& 중간값 & 0.150 & 0.161 & 0.160 & 0.160 \\
현금비율 & 관측치 수 & 1,071 & 1,070 & 1,069 & 1,071 \\
& 평균 & 0.146 & 0.141 & 0.140 & 0.139 \\
& 중간값 & 0.105 & 0.097 & 0.097 & 0.097 \\
\hline
\end{tabular}

패널 $\mathrm{B}$ : 절대금액의 추세

\begin{tabular}{llrrrr}
\hline & & $\mathrm{t}-1$ & $\mathrm{t}$ & $\mathrm{t}+1$ & \multicolumn{1}{c}{$\mathrm{t}+2$} \\
\hline 납입자본금 & 관측치 수 & 1,071 & 1,071 & 1,070 & 1,071 \\
& 평균 & $2,407.35$ & $2,506.73$ & $2,487.02$ & $2,670.67$ \\
& 중간값 & 582.58 & 578.63 & 558.97 & 562.62 \\
이익잉여금 & 관측치 수 & 1,071 & 1,071 & 1,070 & 1,071 \\
& 평균 & $6,179.46$ & $7,022.27$ & $7,682.40$ & $8,451.70$ \\
& 중간값 & $1,096.53$ & $1,198.58$ & $1,324.86$ & $1,432.12$ \\
자본총계 & 관측치 수 & 1,071 & 1,071 & 1,070 & 1,071 \\
& 평균 & $8,863.46$ & $9,677.46$ & $10,412.12$ & $11,255.72$ \\
& 중간값 & $1,918.03$ & $2,028.19$ & $2,131.56$ & $2,296.93$ \\
부채 & 관측치 수 & 1,071 & 1,071 & 1,070 & 1,071 \\
& 평균 & $3,395.39$ & $3,776.71$ & $4,307.82$ & $4,600.88$ \\
& 중간값 & 359.80 & 399.13 & 462.41 & 488.05 \\
현금 & 관측치 수 & 1,071 & 1,070 & 1,069 & 1,071 \\
& 평균 & $1,803.99$ & $1,905.68$ & $2,042.03$ & $2,058.16$ \\
& 중간값 & 343.06 & 367.71 & 389.53 & 430.90 \\
\hline
\end{tabular}


한국증권학회지 제49권 5호 (2020)

평균(중간값)은 $\mathrm{t}-1$ 년 $0.187(0.150)$ 에서 $\mathrm{t}+2$ 년 $0.199(0.160)$ 로 약 $1.2 \% \mathrm{p}(1 \% \mathrm{p})$ 증가하며 현금비율의 평균(중간값)도 $\mathrm{t}-1$ 년 $0.146(0.105)$ 에서 $\mathrm{t}+2$ 년 $0.139(0.097)$ 로 약 $0.7 \% \mathrm{p}(0.8 \% \mathrm{p})$ 의 작은 감소 규모를 나타낸다. 따라서 부채비율과 현금비율이 자사주매입과 함께 큰 변화는 나타나지 않는 것으로 보아 부채조달이나 보유현금이 자사주매입의 주요 재원일 가능성은 높지 않아 보인다.

<표 7>의 패널 $\mathrm{B}$ 는 비율 대신 절대금액(단위: 억 원) 기준으로 자본구조 구성요소와 현금 보유액의 평균과 중간값을 보고하는데, 패널 $\mathrm{A}$ 와 마찬가지로 이익잉여금 증가가 자사주매입 실시의 주 재원일 가능성을 시사한다. 예를 들어 중간값 기준으로 자사주매입 실시기업의 이익 잉여금은 t-1년부터 t+2년까지 큰 폭으로 증가하는데 반해 부채금액의 증가 규모는 상대적으로 작다. 또한 현금보유액은 감소하지 않고 증가하고 있어 보유현금을 자사주매입 주재원으로 사용하는 것으로 보이지 않는다.

\section{5 추가 분석}

\subsection{1 자사주매입 실시기업 vs. 미실시 매칭기업(산업· 기업규모) 비교 분석}

앞서 <표 3>에서 자사주매입 실시기업과 미실시기업의 특성을 비교하여 실시기업은 미실시 기업보다 기업규모가 크고, 기업가치가 높고, 수익성이 높으며 부채비율은 낮고 주가변동성은 작다는 분석결과를 보고하였다. 이번에는 더 엄밀한 비교를 위해 자사주매입 미실시기업 중에서 실시기업과 동일한 산업에 소속되어 있으면서 기업규모가 유사한 매칭기업을 선정한 후 실시기업과 비교·분석하고자 한다.7)

<표 8>은 자사주매입 직전년도를 기준으로 자사주매입을 실시한 표본기업과 매칭기업의 특성을 비교한 결과를 보여주고 있다. 먼저 자사주매입 실시기업의 $\mathrm{M} / \mathrm{B}$ 비율의 평균은 1.363 (중간값 0.897)으로서 매칭기업의 평균인 1.155(중간값 0.843)보다 유의적으로 크게 나타나 자사주매입 기업은 매칭기업보다 기업가치가 높다. 직전년도 주가수익률은 자사주매입 기업이 평균 20.6\%(중간값 6.1\%), 매칭기업이 19.3\%(중간값 6.9\%)로 각각 나타났는데 유의적인 차이를 보이지 않았다. 이는 <표 $3>$ 의 결과와 질적으로 동일한 결과이며 주가저평가가설을 지지하지 않는다. 또한 자사주매입 기업의 $\mathrm{ROA}$ 와 현금흐름은 평균과 중간값에서 모두 매칭기업보다 유의적으로 높게 나타났으며 이외 총자산 증가율, 현금비율, 이익잉여금비율 및 배당-총자산 비율도 모두 평균과 중간값에서 유의적으로 높았다. 한편 부채비율과 주가변동성은 자사주매입 기업의 평균과 중간값이 매칭기업보다 모두 유의적으로 낮은 것으로 나타났다.

7) 이처럼 산업과 기업규모를 사용해 매칭기업을 선정한 선행연구로서 Asker et al.(2015)과 Gao et al.(2013)을 들 수 있다. 본 연구의 구체적인 매칭표본 구축 방법은 다음과 같다. 자사주매입 실시 표본에 포함된 기업연도 관측치 각각에 대해 해당 연도 전후 3년 동안 자사주매입 미실시기업들을 추출한 후 이 중 산업분류코드(한국표준산업분류코드 기준 중분류)가 같고 직전년도말 총자산의 차이(절대값)가 가장 적은 기업을 추출하였다. 복원추출 방식을 통해 총 892 개의 기업연도가 매칭 표본에 포함되었다. 
Korean Firms' Share Repurchase Activities

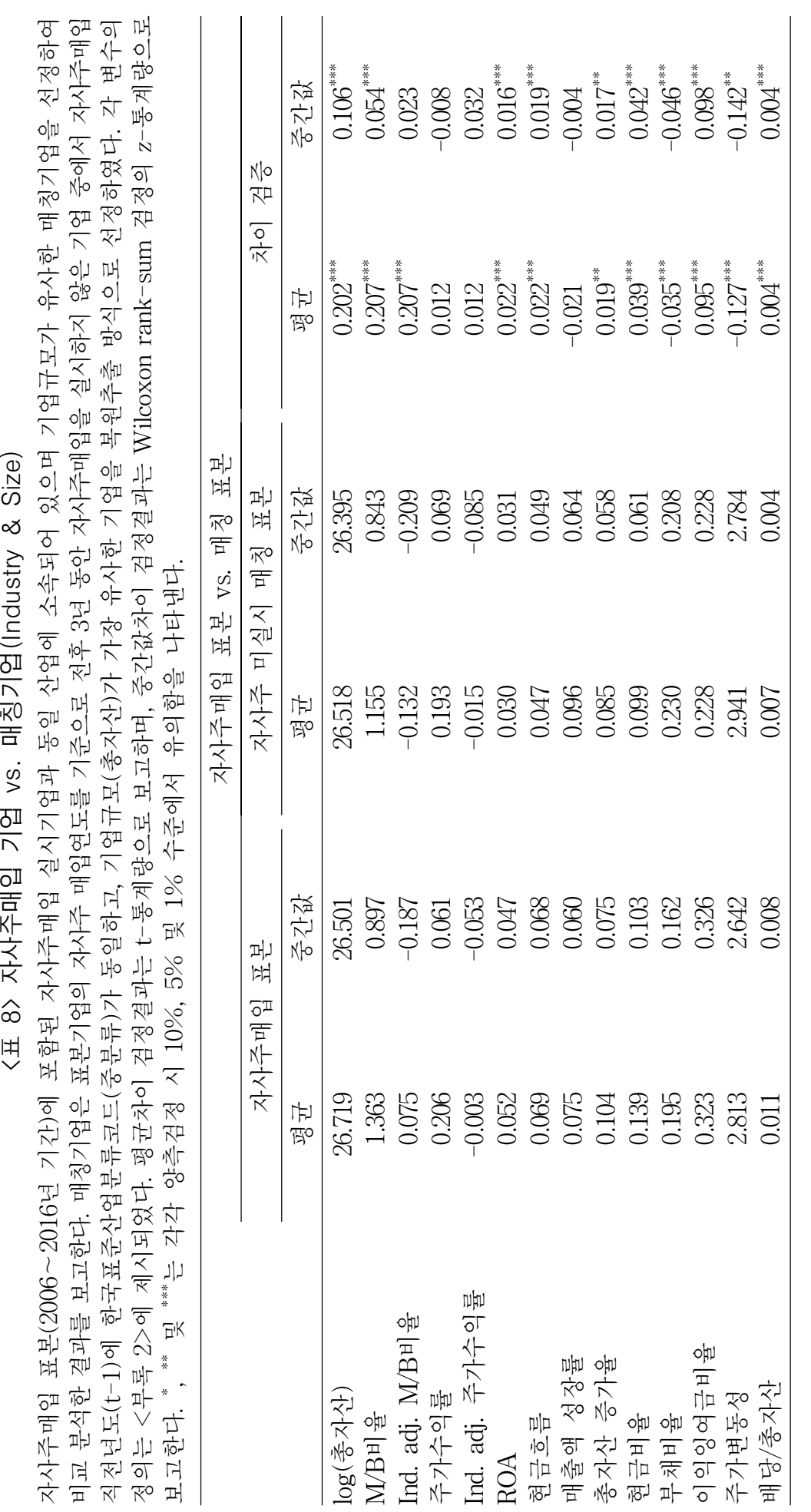


한국증권학회지 제49권 5호 (2020)

이상 자사주매입을 실시한 표본기업과 매칭기업의 특성을 비교·분석한 <표 $8>$ 의 결과를 요약하면, 자사주매입 실시기업은 매칭기업보다 기업가치가 높고 수익성과 현금흐름이 우수하며, 총자산 증가율, 현금비율, 이익잉여금비율 및 배당-총자산 비율이 모두 높은 반면 부채비율은 낮고 주가변동성은 작은 것으로 나타났다. 따라서 매칭기업과의 비교 분석을 통해 <표 $3>$ 의 결과를 재확인할 수 있었다.

\subsection{2 자사주매입 기업의 소극 · 적극투자 여부}

지금까지의 실증분석 결과에 의하면 자사주매입 실시기업은 기업가치가 높고 수익성이 우수하여 많은 현금흐름을 창출하며 그 현금흐름을 이익잉여금의 형태로 쌓으면서 이를 재원으로 자사주매입을 실시하는 것으로 보인다. 따라서 자사주매입 기업이 벌어들인 현금흐름을 유망한 사업에 재투자할 수 있음에도 불구하고 자사주매입을 실시함으로써 성장기회를 살리지 못하는 것은 아닌지 우려가 있다. 본 연구는 Biddle et al.(2009)의 방법론을 이용해 식 (1)과 같은 투자모형을 설정하여, 자사주매입 기업이 소극 또는 적극 투자를 하는가를 가늠하고자 한다.

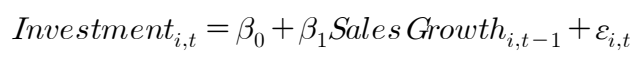

식 (1)의 종속변수인 당해연도 투자 Investment $\left._{i, t}\right)$ 는 [현금흐름표 상 투자활동 현금유출/ 기초시점 $(\mathrm{t}-1)$ 자산총계]이다. 설명변수인 매출액 성장률 $\left(S_{a l e s}\right.$ Growth $\left._{i, t-1}\right)$ 은 [(t-1년 매출액 - t-2년 매출액)/t-2년 매출액]으로 측정한다. 회귀모형은 유가증권시장 전체 기업연도에 대해 추정되며, 추정된 잔차(residual)의 크기를 기준으로 4 분위 하위집단을 생성한다. 잔차의 크기가 하위 25\%에 속하는 하위집단은 실제투자가 기대투자 미만으로 '소극투자'로 간주하며, 상위 $25 \%$ 에 속하는 하위집단은 실제투자가 기대투자 이상으로 '적극투자'로 각각 간주한다. 그리고 잔차의 크기가 중간 수준인 두 개의 하위집단 $\left(2^{\mathrm{nd}} \& 3^{\mathrm{rd}}\right.$ Quartiles $)$ 은 중립적인 투자수준을 나타낸다고 간주한다.

<표 9>의 패널 $\mathrm{A}$ 는 회귀식 (2)에 대한 추정결과를 보고한다. 먼저 유가증권시장 전체기업을 4 분위 하위집단으로 구분한 결과, 소극투자로 분류된 관측치는 전체의 $24.94 \%(1,559$ 개), 중립 투자로 분류된 관측치는 $50.07 \%$ (3,130개), 적극투자로 분류된 관측치는 $24.99 \%(1,562$ 개)를 차지하는 것으로 나타났다. 이는 연구설계에서 의도된 데로 시장 전체로는 기업의 소극투자, 중립투자, 적극투자의 비율이 각각 $25 \%, 50 \%, 25 \%$ 에 수렴함을 의미한다. 하지만 자사주매입 실시기업의 경우 소극투자의 비율이 $18.84 \%$, 중립투자의 비율이 $50.98 \%$, 적극투자의 비율이 $30.18 \%$ 로 나타나, 자사주매입 기업은 소극투자보다는 적극투자의 성향이 높은 것으로 나타났다. 한편 매칭기업은 소극투자의 비율이 $30.26 \%$, 중립투자의 비율이 $49.04 \%$, 적극투자의 비율이 $20.07 \%$ 로서 자사주매입 기업에 비해 소극투자의 비율은 높은 반면 적극투자의 비율은 낮게 나타났다. 따라서 분석 결과는 자사주매입 기업이 소극적인 투자활동을 벌인다는 추측을 지지하지 않는다.

추가로 자사주매입 기업의 소극·적극적 투자 여부를 재차 확인하기 위해 3년 누적 투자규모를 종속변수로 설정한 식 (2)를 추정한다. 구체적으로 3 년 누적 투자규모 $\left(\sum\right.$ Investment $\left._{i,(t=0, t=2)}\right)$ 는 
[3년 누적 투자활동 현금유출액/기초시점(t-1) 자산총계]이며 설명변수는 식 (1)과 동일하다.

$$
\text { Investment }_{i,(t=0, t=2)}=\beta_{0}+\beta_{1} \text { Sales }_{\text {Growth }} \text { Int }-1_{1}+\varepsilon_{i, t}
$$

<표 9>의 패널 B는 회귀식 (2)를 사용해 소극 또는 적극투자 성향을 추정한 결과를 보고하는데. 자사주매입 기업은 소극투자의 확률이 $17.92 \%$, 중립투자 확률이 $51.78 \%$, 적극투자의 확률이 $30.30 \%$ 로 나타났다. 따라서 당해연도 투자규모를 종속변수로 설정한 식 (1)에 대한 실증분석 결과와 마찬가지로 자사주매입 기업은 소극적보다는 적극적 투자를 실시하는 성향이 높음을 시사한다.

\section{〈표 9〉 자사주 매입기업의 소극 - 적극투자 여부}

자사주매입 표본(2006 2016년 기간)에 포함된 자사주매입 실시기업의 소극·적극투자 여부를 유가증권 시장 전체기업과 매칭기업과 비교하여 분석한다. 매칭기업 선정 방법은 <표 8>에서 기술한 방법과 동일하다. 소극·적극투자 여부의 판단은 Biddle et al.(2009)의 투자회귀모형에 기초한 방법론을 이용하였다. 패널 $\mathrm{A}$ 의 추정회귀모형은 'Investment $\mathrm{i}_{\mathrm{i}, \mathrm{t}}=\beta_{0}+\beta_{1}$. 매출액 성장률, ${ }_{\mathrm{i},-1}{ }^{+} \varepsilon_{\mathrm{i}, \mathrm{t}}$ '이며, 종속변수인 Investment $\mathrm{i}_{\mathrm{i}, \mathrm{L}}$ 는 (현금 흐름표 상) t년 투자활동으로 인한 현금유출액을 기초시점(t-1) 자산총계로 나눈 값이다. 패널 $\mathrm{B}$ 의 추정회귀

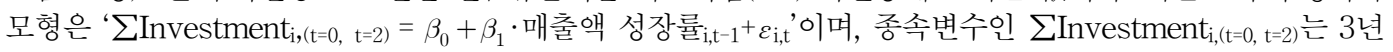
누적 현금유출액을 기초시점(t-1) 자산총계로 나눈 값이다. 회귀모형은 유가증권시장 전체 기업연도에 대해 추정되며, 추정된 잔차(residual)의 크기를 기준으로 4 분위 하위집단을 생성한다. 잔차의 크기가 하위 $25 \%$ 에 속하는 하위집단은 '소극투자'로 상위 $25 \%$ 에 속하는 하위집단은 '적극투자'로 간주한다. 잔차의 크기가 중간 수준인 두 개의 하위집단( $2^{\text {nd }} \& 3^{\text {rd }}$ Quartiles)은 소극 또는 적극투자를 하지 않는 '중립투자'로 간주한다.

패널 $\mathrm{A}:$ Investmenti,t가 종속변수인 투자회귀모형의 잔차를 사용한 분류

\begin{tabular}{llcrc}
\hline & & 유가증권시장 & 자사주매입 표본 & 매칭 표본 \\
\hline 소극투자 & 관측치 수 & 1,559 & 201 & 269 \\
& 비중(\%) & 24.94 & 18.84 & 30.26 \\
중립투자 & 관측치 수 & 3,130 & 544 & 436 \\
& 비중(\%) & 50.07 & 50.98 & 49.04 \\
적극투자 & 관측치 수 & 1,562 & 322 & 184 \\
& 비중(\%) & 24.99 & 30.18 & 20.07 \\
\hline
\end{tabular}

패널 B: $\sum$ Investmenti, $(\mathrm{t}=0, \mathrm{t}=2)$ 가 종속변수인 투자회귀모형의 잔차를 사용한 분류

\begin{tabular}{llcrc}
\hline & & 유가증권시장 & 자사주매입 표본 & 매칭 표본 \\
\hline 소극투자 & 관측치 수 & 1,554 & 191 & 259 \\
& 비중(\%) & 24.93 & 17.92 & 29.20 \\
중립투자 & 관측치 수 & 3,122 & 552 & 431 \\
& 비중(\%) & 50.08 & 51.78 & 48.59 \\
적극투자 & 관측치 수 & 1,558 & 323 & 197 \\
& 비중(\%) & 24.99 & 30.30 & 22.21 \\
& & &
\end{tabular}

결론적으로 자사주매입 기업이 유가증권 전체기업 또는 매칭기업에 비해 소극적 투자를 한다는 증거는 발견되지 않았으며 오히려 적극투자 성향이 더 높은 것으로 나타났다. 
한국증권학회지 제 49 권 5 호 (2020)

\subsection{3 자사주매입 vs. 배당지급 규모에 영향 미치는 기업특질 비교 분석}

앞서 <그림 $1>$ 에서 확인하였듯이 한국의 상장기업은 자사주매입보다는 배당지급을 주된 지급수단으로 사용하고 있으나 실증분석 결과 자사주매입 실시여부와 그 규모는 기업가치, 현금흐름, 기업규모 등과 유의한 양(+)의 관계가 있음을 알 수 있었다. 그런 데 지급수단으로써 자사주매입의 성격을 면밀하게 파악하기 위해서는 주요 기업특질이 자사주매입에 미치는 효과를 배당에 미치는 효과와 비교하여 분석할 필요가 있다. 특히 미국의 선행연구에 의하면 배당지급은 주가변동성으로 측정한 현금흐름 불확실성과는 음 $(-)$ 의 관계, 이익잉여금비율로 측정한 재무적 성숙도와는 양(+)의 관계가 있으나, 기업가치와는 유의한 관계가 뚜렷하게 나타나지 않는다 (DeAngelo et al., 2006; Chay and Suh, 2009). 본 절의 분석에서는 이 기업특질들이 자사주매입과 배당지급에 미치는 영향을 회귀분석을 통해 비교해 보고자 한다.

<표 10>은 자사주매입 vs. 배당 규모의 결정요인을 Tobit 회귀분석을 통해 비교한 결과를 보고한다. 표본에는 유가증권시장 소속기업 전체가 포함되었으며 종속변수는 3년 누적 자사주

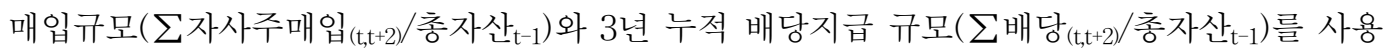
하였다.

먼저, 모형 (1)과 (9)에서 $\mathrm{M} / \mathrm{B}$ 비율은 모두 종속변수인 자사주매입 규모에 유의한 양(+)의 영향을 미치는 것으로 나타나, 기업가치가 높을수록 자사주매입 규모가 커지는 것으로 나타난다. 하지만 모형 (2)와 (10)에서 M/B비율은 종속변수인 배당 규모에 유의한 음(-)의 영향을 미치거나 유의적인 영향이 없다. 따라서 기업가치가 높은 기업이 자사주매입을 실시하는 경향이 높은 반면, 기업가치와 배당 간에는 양(+)의 관계가 나타나지 않는다. 모형 (3)과 (4)에서 현금흐름은 종속변수인 자사주매입과 배당지급에 모두 유의한 양 $(+)$ 의 영향을 미치는 것으로 나타났다. 하지만, 계수값 차이를 검토한 결과 현금흐름은 자사주매입보다 배당지급에 더 유의적인 양(+)의 영향을 나타내는 것으로 나타났다.

현금흐름 불확실성의 대용치인 주가변동성은 자사주매입에는 $10 \%$ 수준에서 유의한 음(-)의 영향을 미치거나(모형 (5)) 유의한 영향을 미치지 않는 반면(모형 (9)), 배당지급에는 $1 \%$ 수준에서 유의한 음(-)의 영향을 미치는 것으로 나타났다(모형 (6)과 (10)). 또한 계수값 차이를 분석한 결과 주가변동성은 자사주매입보다는 배당에 더 유의한 음(-)의 효과를 나타내고 있다. 한편 재무적 성숙도의 대용치인 이익잉여금비율은 모형 (7)과 (8)에서는 자사주매입과 배당지급에 모두 유의한 양 $(+)$ 의 영향을 미치는 것으로 나타났지만, 모형 (9)과 (10)에서 설명변수를 추가하고 난 후에는 자사주매입에는 유의한 영향을 미치지 않는 반면, 배당지급에는 유의한 양(+)의 영향을 미치는 것으로 나타났다. 따라서 이익잉여금비율은 자사주매입보다는 배당지급에 더 영향을 미치는 변수로 판단된다.

요약하자면, 자사주매입 규모는 배당지급 규모와는 달리 $\mathrm{M} / \mathrm{B}$ 비율과 유의한 양(+)의 관계를 가지며, 배당지급 규모는 자사주매입 규모와 비교해 현금흐름과 이익잉여금비율과의 양 $(+)$ 의 관계가 더 강하지만 주가변동성과는 음 $(-)$ 의 관계가 더 강하다. 따라서 자사주매입은 (배당과 비교해) 기업가치가 높을수록 그 규모가 높아지는 경향이 있으며, 배당지급은 (자사주매입과 


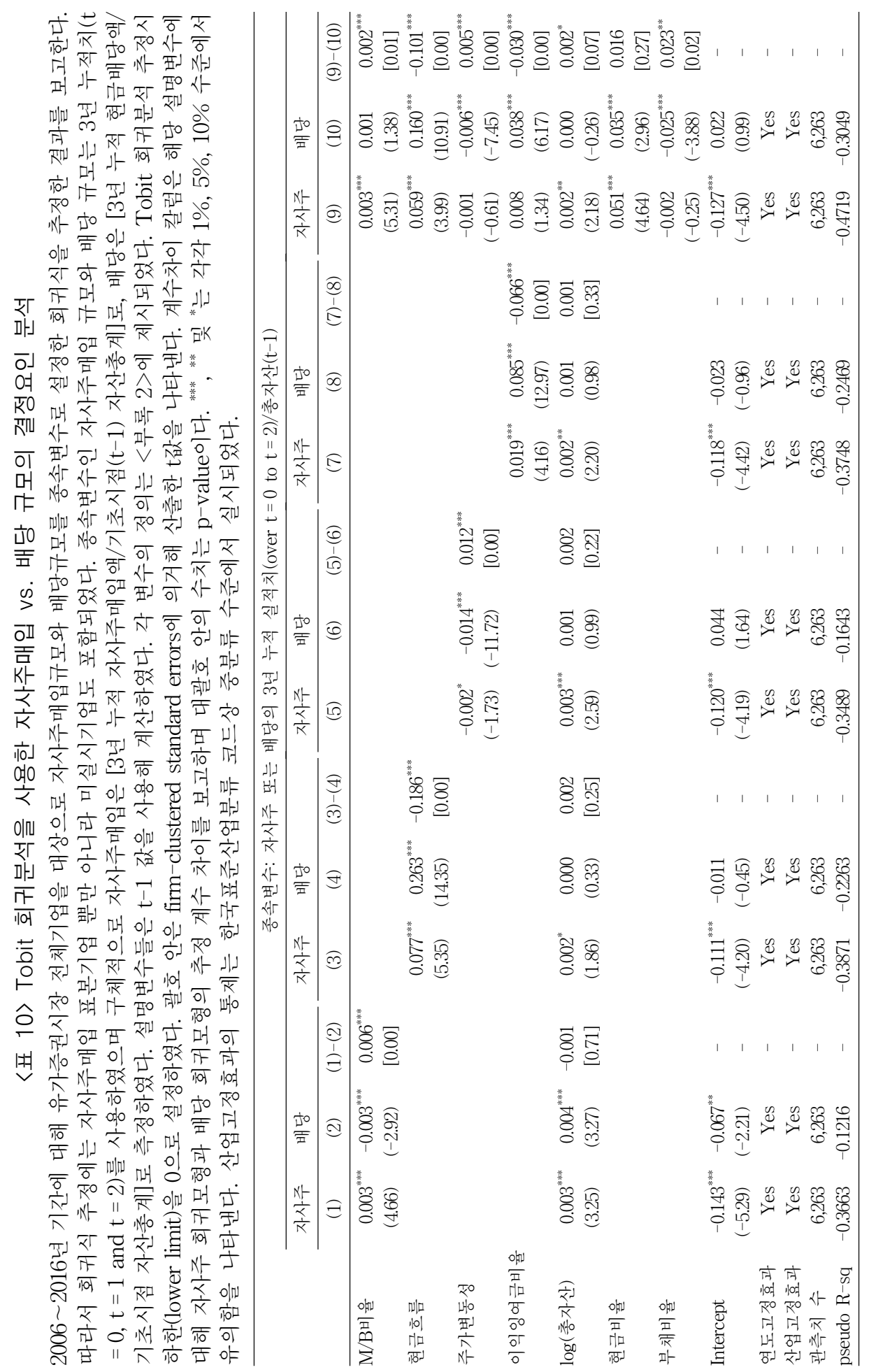




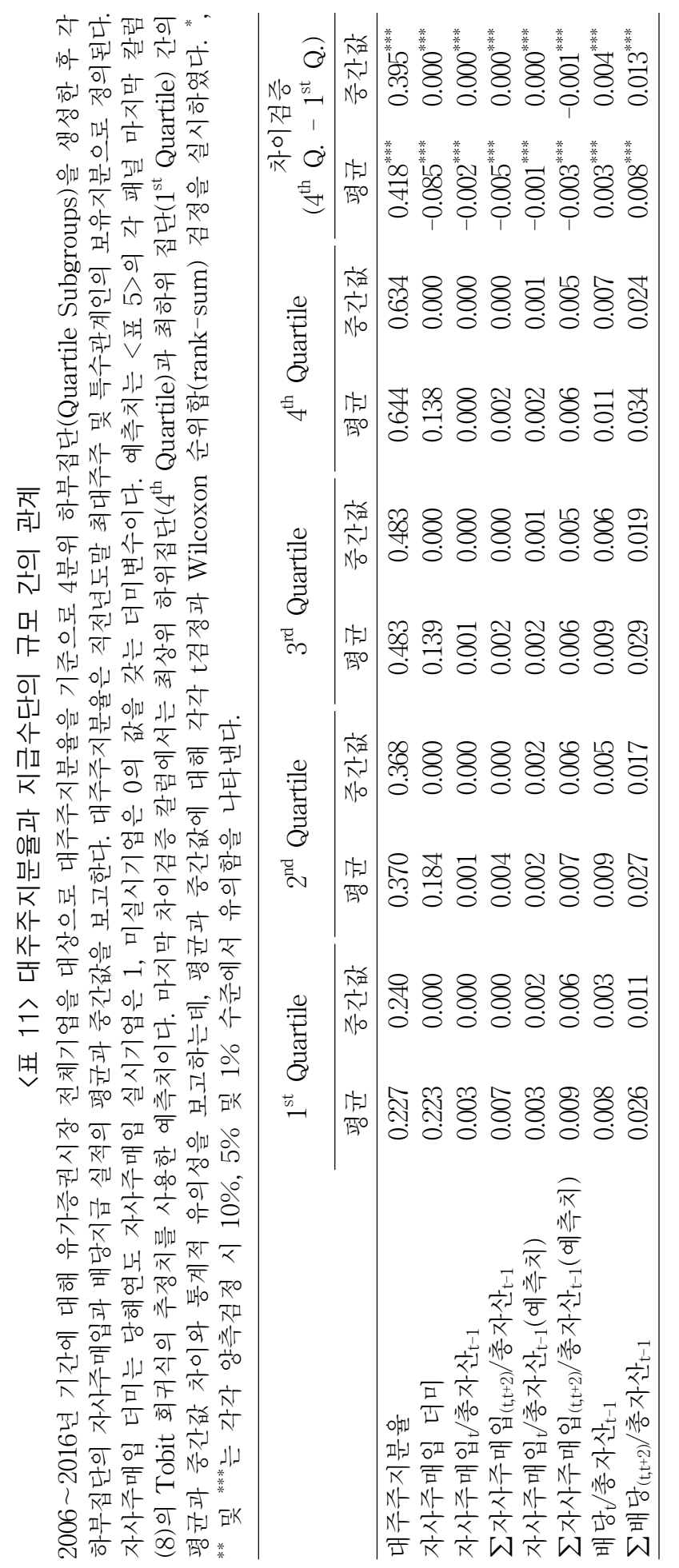


Korean Firms' Share Repurchase Activities

비교해) 현금흐름이 좋거나 재무적 성숙도가 높을수록 그 규모가 높아지며 주가변동성이 높을 경우 그 규모가 작아지는 경향이 있다.

\subsection{4 대주주지분율과 지급정책}

마지막으로 대주주지분율이 지급방식의 선택과 실시규모에 미치는 영향을 탐구한다. 1994 2002년 기간의 자사주매입 공시자료를 분석한 Lee and Joo(2005)는 대주주지분율과 자사주매입 간의 유의적인 관계를 발견하지 못한 바 있다. 반면 Park(2011)의 1999 2008년 기간에 대한 자사주매입 더미변수와 배당 더미변수를 구축한 후 배당지급기업의 최대주주지분율이 자사주 매입기업의 최대주주지분율보다 높음을 보고한다. 이와 유사하게 Ko and Joh(2009)도 1998 2005 년 기간에 대한 분석을 통해 지배주주의 지분율이 자사주매입 확률과는 음(-)의 관계, 그리고 배당실시 확률과는 양(+)의 관계를 가짐을 보고한다.

<표 11>에서는 2006 2016년 기간에 대해 개별기업의 내부지분율(최대주주 및 특수관계인의 보유지분)을 기준으로 유가증권 소속기업을 4 분위(Quartiles)로 나눈 후 각 분위 소속기업의 자사주매입과 배당 규모를 분석하였다.

표에 보고된 평균과 중간값에 따르면 대주주지분율이 증가할수록 자사주매입의 빈도와 규모가 감소하는 경향이 있다. 예를 들어 내부지분율 1 분위 소속기업 중 자사주매입 실시기업의 비율은 $22.3 \%$ (즉 자사주매입 더미변수의 평균값)인데 반해 2분위 $18.4 \%, 3$ 분위 $13.9 \%, 4$ 분위 $13.8 \%$ 로 차츰 감소한다. 3 년 누적 자사주매입 규모는 1 분위 소속기업의 평균(중간값)은 $0.007(0.000)$ 이나 2 분위 $0.004(0.000), 3$ 분위 $0.002(0.000), 4$ 분위 $0.002(0.000)$ 로 낮아지는 경향이 있다. 하지만 이와 대조적으로 배당 규모는 대주주지분율이 증가할수록 증가하는 패턴이 있다. 예를 들어 3 년 누적 배당규모의 경우 1 분위 소속기업의 평균(중간값)은 $0.026(0.011)$ 인데 반해 2 분위 0.027(0.017), 3분위 0.029(0.019), 4분위 0.034(0.024)로 대주주지분율에 따라 높아지는 경향을 나타낸다.

결론적으로 대주주지분율이 낮은 기업은 자사주매입을 지급수단으로 선호하고 대주주지분율이 높은 기업은 배당을 지급수단으로 선호하는 경향이 발견되었다. 이는 표본기간은 다르지만 $\operatorname{Park}(2011)$ 과 Ko and Joh(2009)의 분석결과와 일관된 것이다. 해석하자면, 대주주지분율이 낮은 기업의 경우 대주주의 지분율 강화 수단으로 자사주매입을 실시하는 동기가 반영된 것으로 보인다. 또한 대주주지분율이 이미 높은 수준인 기업의 경우 대주주가 배당을 통해 현금지급을 받고자 하는 동기가 반영된 것으로 해석될 수 있다.

\section{5. 결어: 논문의 한계와 향후 연구}

본 연구는 국내 선행연구와는 달리 기업의 현금흐름표 상 연간 자사주매입 규모를 분석하였으며 상대적으로 최근 기간의 한국기업의 자사주매입 의사결정에 미치는 기업특성을 분석하였다. 또한 선행연구가 다루지 않은 자사주매입의 재원, 자본구조와의 관련성, 배당지급과의 특성 차이 등을 분석하였다. 
분석 결과 중 기업가치가 높을수록 자사주매입 규모가 높지만 직전년도 주가수익률과 자사주 매입 규모 간에 유의한 관계가 없다 등의 현상은 주가저평가가설을 지지하지 않는다. 물론 이 결론은 미국기업의 자사주매입에 관한 최근 연구인 El Ghoul et al.(2020), Lee et al.(2020a, $2020 \mathrm{~b})$ 의 관측과 일관성이 있지만 해석에 신중을 기할 필요가 있다. 즉, 본 논문은 통계분석을 통해 평균적인 경향을 판단하여 가설의 지지와 기각을 결정하는데 반해, 실제에서는 적지 않은 수의 기업들이 주가 부진을 탈피하려는 방편으로 자사주매입을 실시하고 있을 가능성도 있다. 예를 들어 한국거래소의 "2011년도 자기주식 취득·처분 현황 분석(보도자료)”에 따르면, 2011년 동안 자사주식 취득 기업의 절대 다수가 “주가안정”을 자사주 취득 목적으로 공시하였다. 물론 “주가안정”은 매우 포괄적인 표현이기 때문에 이에 대해서는 여러 대체적인 해석이 가능하다.

향후 유망한 관련 연구 주제로는 “비즈니스그룹의 내부시장에서 자사주매입과 배당이 담당하는 역할”과 “기관투자자들이 자사주매입과 배당지급에 미치는 역할”을 생각할 수 있다.8) 첫 번째 주제와 관련해 기업의 지급정책의 유형과 규모는 해당 기업이 비즈니스그룹에서 모회사, 자회사, 손자회사인가 또는 성장사업 vs. cash cow 사업을 담당하는가에 따라 달라질 수 있을 것이다. 또한 순수지주회사 형태의 모회사의 영업수익은 자회사로부터의 배당수취에 많이 의존하기 때문에 순수지주회사가 지배하는 사업자회사는 자사주매입보다는 배당지급을 주된 지급정책 으로 선택할 가능성이 높다. 이 같은 예측에 대한 후속 연구의 성과를 기대해 본다.

8) 논문에 표로 보고하지는 않았지만, 저자들은 대규모기업집단 소속인가 아닌가(공정거래위 자료를 이용해 구분)에 따라 기업의 자사주매입 규모가 달라지는가를 분석하였는데 대규모기업집단 소속기업 vs. 비소속기업 간 유의적인 차이를 발견하지 못하였다. 


\section{References}

Asker, J., J. Farre-Mensa, and A. Ljungqvist, 2015, Corporate Investment and Stock Market Listing: A Puzzle?, Review of Financial Studies, Vol. 28 (2), pp. 342-390.

Bargeron, L., A. Bonaimé, and S. Thomas, 2017, The Timing and Source of Long-run Returns Following Repurchases, Journal of Financial and Quantitative Analysis, Vol. 52 (2), pp. 491-517.

Biddle, G. C., G. Hilary, and R. S. Verdi, 2009, How Does Financial Reporting Quality Relate to Investment Efficiency? Journal of Accounting and Economics, Vol. 48 (1-2), pp. $112-131$.

Billett, M., and H. Xue, 2007, The Takeover Deterrent Effect of Open Market Share Repurchases, Journal of Finance, Vol. 62 (4), pp. 1827-1850.

Bonaimé, A., Ö. Öztekein, and R. Warr, 2014, Capital Structure, Equity Mispricing and Stock Repurchases, Journal of Corporate Finance, Vol. 26, pp. 182-200.

Byun, J., 2004, Signaling Effects and the Long-term Performance of False Signaling Firms: Evidence from the Undervaluation Stock Repurchases, Korean Journal of Financial Studies, Vol. 33 (1), pp. 207-248.

Byun, J., and M. Pyo, 2006, Majority Shareholders Selling Behavior after the Repurchasing Announcement: Signaling ot Managerial Oppotunism? Korean Managment Review, Vol. 35 (3), pp. 695-716.

Chay, J., and J. Suh, 2009, Payout Policy and Cash Flow Uncertainty, Journal of Financial Economics, Vol. 93 (10), pp. 88-107.

Chen, S., and Y. Wang, 2012, Financial Constraints and Share Repurchases, Journal of Financial Economics, Vol. 105 (2), pp. 311-331.

Choi, H., W. Sohn, and S. Lee, 2011, Signaling Effect of Stock Repurchase Announcement and Discretionary Accruals of Korean Firms, Journal of Korean Economics Studies, Vol. 29 (1), pp. 103-131.

DeAngelo, H., L. DeAngelo, and R. Stulz, 2006, Dividend Policy and the Earned/Contributed Capital Mix: A Test of the Life-Cycle Theory, Journal of Financial Economics, Vol. 81 (2), pp. 227-254.

Dittmar, A., 2000, Why Do Firms Repurchase Stocks? Journal of Business, Vol. 73 (3), pp. 331-355.

El Ghoul, S., O. Guedhami, H. Kim, and J. Suh, 2020, Persistence of Share Repurchases, Financing and Growth, Working Paper, http://www.iksa.or.kr/modules/bbs/index.php?c ode=search_1\&mode=view\&id=3366\&page=4\&__M_ID=187\&sfield=\&sword. 
한국증권학회지 제49권 5 호 (2020)

Fenn, G. W., and N. Liang, 2001, Corporate Payout Policy and Managerial Stock Incentives, Journal of Corporate Finance, Vol. 60 (1), pp. 45-72.

Gao, H., J. Harford, and K. Li, 2013, Determinants of Corporate Cash Policy: A Comparison of Private and Public Firms, Journal of Financial Economics, Vol. 109, pp. 623-639.

Guay, W., and J. Harford, 2000, The Cash-Flow Permanence and Information Content of Dividend Increases versus Repurchases, Journal of Financial Economics, Vol. 57 (3), pp. 385-415.

Hribar, P., N. Jenkins, and W. Johnson, 2006, Stock Repurchases as an Earnings Management Device, Journal of Accounting and Economics, Vol. 41 (1-2), pp. 3-27.

Jagannathan, M., C. Stephens, and M. S. Weisbach, 2000, Financial Flexibility and the Choice between Dividends and Share Repurchases, Journal of Financial Economics, Vol. 57 (3), pp. 355-384.

Jung, S., and Y. Lee, 2003, The Long-term Performance of Repurchased Stocks, Korean Journal of Finance, Vol. 16 (2), pp. 129-162.

Kim, H., and S. Yoon, 2010, The Impact of Controlling Shareholders' Wedge on Share Repurchases and Cash Dividens, Korean Managment Review, Vol. 39 (6), pp. 1477-1503.

Kim, S., 2003, Information Effect of Share Repurchase, Korean Journal of Financial Management, Vol. 9 (1), pp. 69-93.

Kim, T., and H. Kim, 2019, Institutional Investment Horizons and Share Repurchases, Asian Review of Financial Research, Vol. 32 (2), pp. 221-246.

Kim, W., and J. Lim, 2017, An Empirical Study on Resale and Retirement of Treasury Shares: Evidence from Korea, Korean Journal of Financial Studies, Vol. 46 (1), pp. 35-72.

Kim, Y., and S. Jung, 2008, The Determinants of Stock Repurchase Methods and the Test of Opportunistic Behavior Hypothesis, Korean Managment Review, Vol. 37 (5), pp. 1205-1232.

Ko, Y., and S. Joh, 2009, The Effect of Ownership Structure on Payout Policy, Asian Review of Financial Research, Vol. 22 (3), pp. 35-72.

Lee, B., and J. Suh, 2011, Cash Holdings and Share Repurchases: International Evidence, Journal of Corporate Finance, Vol. 17 (5), pp. 1306-1329.

Lee, D. W., H. Shin, and R. M. Stulz, 2020a, Why Does Equity Capital Flow out of High Tobin's Q Industries, Review of Financial Studies, Accepted Manuscript, https://doi.org/1 0.1093/rfs/hhaa086.

Lee, I., and S. Joo, 2005, A Study on the Stock Repurchase Motives, Korean Journal of Financial Management, Vol. 11 (1), pp. 243-273. 
Korean Firms' Share Repurchase Activities

Lee, I., Y. Park, and N. D. Pearson, 2020b, Repurchases After being Well Known after Good News, Journal of Corporate Finance, Vol. 62, https://doi.org/10.1016/j.jcorpfin.2019.101552. Lee, W., and S. Choi, 2010, Value Relevance on the Treasury Stock Repurchase, Accounting Information Review, Vol. 28 (1), pp. 1-31.

Lim, B., and S. Park, 2018, Managerial Timing Ability and Share Repurchases, Korean Journal of Financial Studies, Vol. 47 (1), pp. 131-164.

Park, J., 2011, Stock Repurchase vs. Cash Dividends: Choosing Between the Two and Illiquidity Premium, Asian Review of Financial Research, Vol. 24 (1), pp. 1-40.

Stephens, C., and M. Weisbach, 1998, Actual Share Reacquisitions in Open Market Repurchase Programs, Journal of Finance, Vol. 53 (1), pp. 313-333. 


\section{〈부록〉}

\section{〈부록 1〉 자사주매입 실시 표본 구축과정}

자사주매입 실시 표본 구축과정을 보고한다. 표본 기간의 시작년도는 FnGuide 데이터베이스에서 자기주식의 취득 및 처분에 대한 유효한 자료를 구할 수 있는 2006년이며 최종적으로 자사주매입 표본에는 2006 2016년 기간에 대해 총 1,071 개의 기업연도 관측치(396개의 고유기업 관측치)가 포함되었다. 실제 분석기간은 2006 2018년인데 이는 자사주매입 후 2년이 경과한 시점(t+2년)까지의 변화를 분석하기 때문이다.

\begin{tabular}{lr}
\hline \multicolumn{1}{c}{ 단계 } & 기업연도 관측치 수 \\
\hline $\begin{array}{l}\text { 1. 2006 2016년 기간 유가증권시장 소속기업 중 현금흐름표 상 자사주 취득금액이 } \\
\text { 양(+)인 기업연도 }\end{array}$ & 1,326 \\
2. 금융회사(산업분류코드 64-66) 제외 & $(6)$ \\
3. 매출자료 누락된 기업연도 제외 & $(1)$ \\
4. 자본잠식 기업연도(즉, 자본총계가 음인 경우) 제외 & $(2)$ \\
5. 자사주 순매입금액이 0 또는 음(-)의 값인 기업연도 제외 & $(120)$ \\
6. 주요 기업특성변수가 결측치인 기업연도 제외 & $(126)$ \\
& 최종 표본 \\
\hline & 1,071 \\
\hline 기업연도(firm-year) 관측치 수 & 396 \\
고유기업(unique firm) 관측치 수 & 1,071 \\
\hline
\end{tabular}

\section{〈부록 2〉변수 정의}

주요 변수의 정의를 보고하며, 괄호 안의 숫자는 FnGuide 데이터베이스의 코드번호이다.

\begin{tabular}{|c|c|}
\hline 자사주매입 $t$ 총자산 $t-1$ & $\begin{array}{l}\text { 당해연도 }(\mathrm{t}=0) \text { 자사주 순매입금액/전년도 }(\mathrm{t}=-1) \text { 총자산 }(1001190010) ; \\
\text { *순매입금액 = 자기주식의 취득 }(1001330600)-\text { 자기주식의 처분 }(1001330260)\end{array}$ \\
\hline 자사주매입(t,t+1)/총즈 & 2 년 누적 $(\mathrm{t}=0, \mathrm{t}=1)$ 자사주 순매입금액/전년도 $(\mathrm{t}=-1)$ 총자산 $(1001190010)$ \\
\hline $\begin{array}{l}\sum \text { 자사주매입 }(\mathrm{t}, \mathrm{t}+2) / \text { 총자산 } \mathrm{t}-1 \\
\log \text { (총자산) }\end{array}$ & $\begin{array}{l}3 \text { 년 누적 }(\mathrm{t}=0, \mathrm{t}=1, \mathrm{t}=2) \text { 자사주 순매입금액/전년도 }(\mathrm{t}=-1) \text { 총자산 }(1001190010) \\
\text { 총자산 }(1001190010) \text { 에 자연로그 취한 값 }\end{array}$ \\
\hline I/B비율 & $\begin{array}{l}\text { [총자산(4001190010)-자본의 장부가치 }+ \text { 자본의 시장가치)]/총자산; 자본의 장부 } \\
\quad \text { 가치 }=\text { 자본총계 }(4001190380)-\text { 우선주 자본금(4001130090) \& 자본의 시장가치 } \\
\quad=\text { 주가 }(\mathrm{S} 430003700) \times \text { 상장주식수 }(\mathrm{S} 430001300)\end{array}$ \\
\hline 주가수익률 & [주가(S430003700)-전년도 주가(S430003700)]/전년도 주가(S430003700) \\
\hline $\mathrm{ROA}$ & 430)/총자산(1001190010) \\
\hline 현금흐름 & $\begin{array}{l}\text { [당기순이익(1001212450)+감가상각비(1001310330)] } \\
\quad \text { /전년도 총자산(1001190010) }\end{array}$ \\
\hline 매출액 성장률 & [매출액(1001210000)-전년도 매출액(1001210000)]/전년도 매출액(1001210000) \\
\hline 총자산 증가율 & [총자산(1001190010)-전년도 총자산(1001190010)]/전년도 총자산(1001190010) \\
\hline 현금비율 & $\begin{array}{l}\text { 현금/총자산(1001190010); 현금 = 현금 및 현금성 자산(1001190370) } \\
\quad+\text { 유동금융자산(1001190270) }\end{array}$ \\
\hline 부채비율 & $\begin{array}{l}\text { 부채/총자산(1001190010); 부채 = 단기사채(1001181470) + 단기차입금(1001121700) } \\
\quad \text { +유동금융부채(1001190630)+유동성 장기부채(1001190620)+사채(1001190460) } \\
\text { +장기차입금(1001190470)+비유동금융부채(1001190480) }\end{array}$ \\
\hline 이익잉여금비율 & 이익잉여금(1001130470)/총자산(1001190010) \\
\hline 가변동성 & 가수익률(S41000170F)의 표준편차 \\
\hline 사산 & 현금배당(3001705002)/전년도 총자산(1001190010) \\
\hline vestment & 투자활동으로 인한 현금유출액(1001390270)/전년도 총자산(1001190010) \\
\hline
\end{tabular}


Korean Firms' Share Repurchase Activities

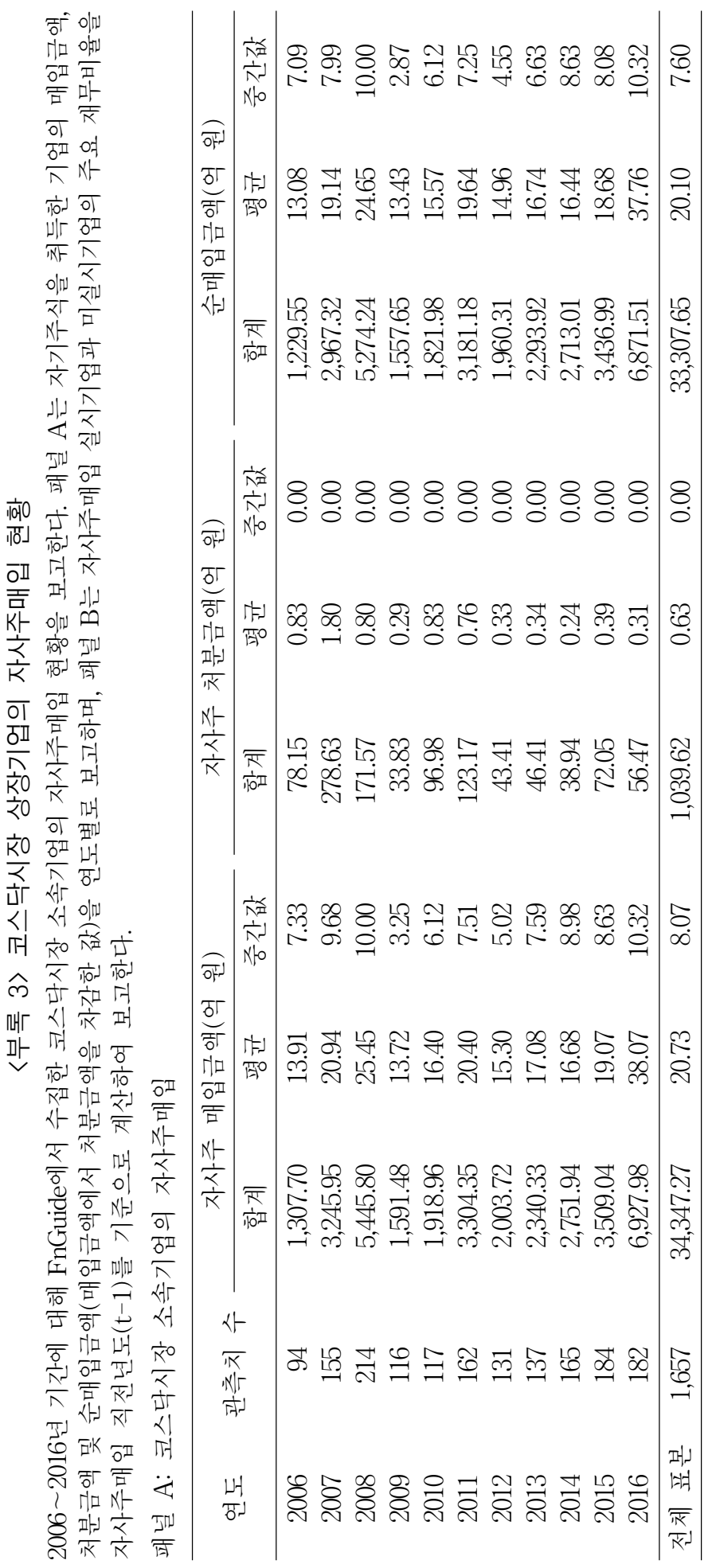




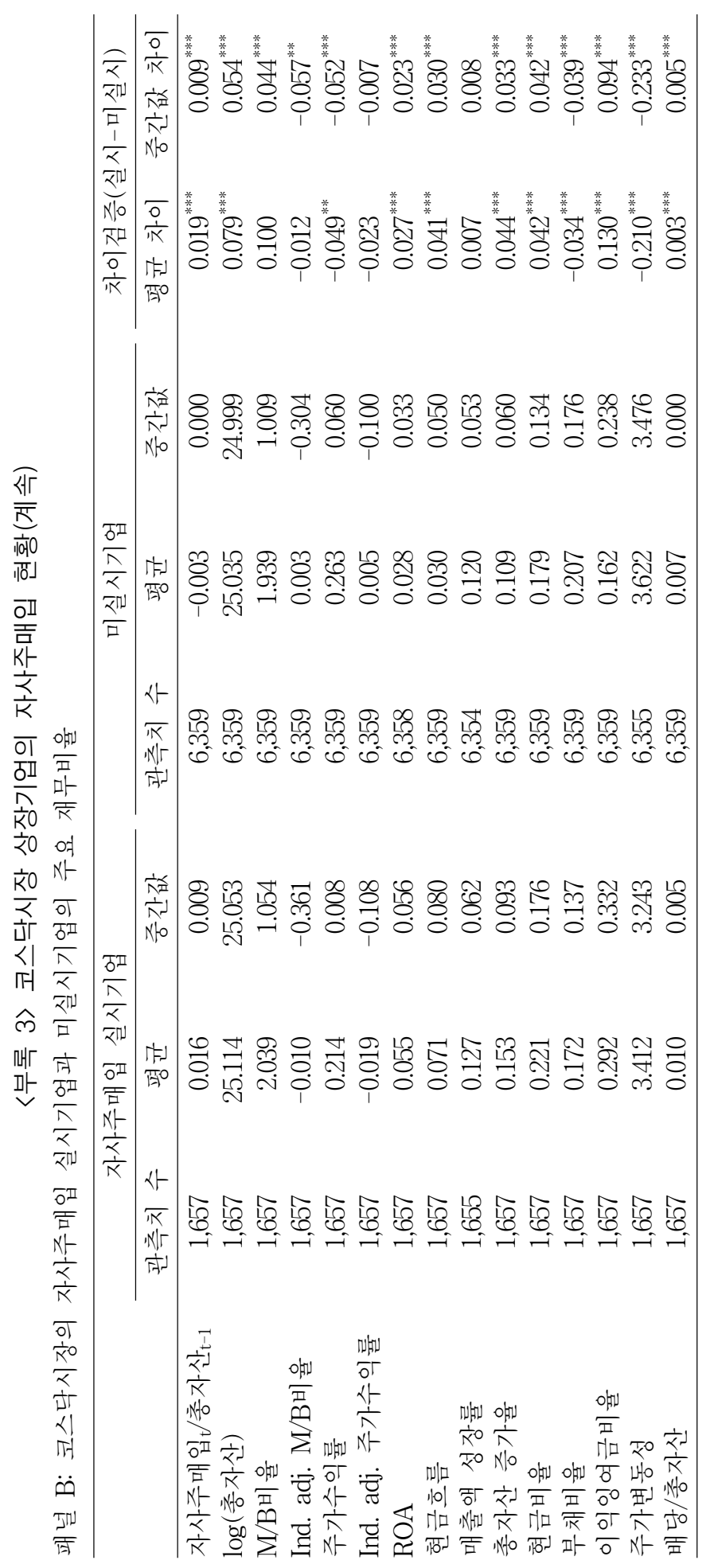

